Research Article

\title{
Confirmed Mechanism for 1,8-Diaminonaphthalene and Ethyl Aroylpyrovate Derivatives Reaction, DFT/B3LYP, and Antimicrobial Activity of the Products
}

\author{
Sraa Abu-Melha ii \\ Department of Chemistry, Faculty of Science of Girls, King Khaled University, Abha, Saudi Arabia \\ Correspondence should be addressed to Sraa Abu-Melha; sabomlha@kku.edu.sa
}

Received 2 May 2018; Accepted 10 September 2018; Published 10 December 2018

Academic Editor: Xinyong Liu

Copyright () 2018 Sraa Abu-Melha. This is an open access article distributed under the Creative Commons Attribution License, which permits unrestricted use, distribution, and reproduction in any medium, provided the original work is properly cited.

\begin{abstract}
Two new series of perimidine derivatives were prepared from the reaction of 1,8-diaminonaphthalene with ethyl aroylpyrovate followed by coupling for the products. The structures, the mechanism, and the tautomeric forms of the products have been discussed on the basis of spectral data aided with the computational study. Applying Guassian09 software, the reaction mechanism was assured. The energy contents were computed after optimization for all proposed structures. The likely extracted compound has a reduced heat during formation and internal energy which coincides with experimental outcomes. The antimicrobial activity of all products was screened, and their results indicated the presence of five derivatives more potent than the reference drugs used. The simulation procedure was executed by Autodock 4.2 tools over the expected compounds yielded (12 and 21). This computational technique asserts on the drug behavior inside the causative organism proteins. The organisms here match with that used in the antimicrobial and antifungal study.
\end{abstract}

\section{Introduction}

It was reported that the reaction of 1,2-diaminoaromatic compound $\mathbf{1}$ with 1,2-dicarbonyl compounds $\mathbf{2}$ or $\mathbf{3}$ afforded the quinoxaline or pyrazin-2(1H)-one derivatives $\mathbf{4}$ and $\mathbf{5}$ $[1,2]$. However, condensation of 1,8-diaminonaphthalene with benzil 2 or alkyl carboxylate derivative of 3 -furanone 7 furnished the perimidine derivatives $\mathbf{8}$ and $\mathbf{9}$, respectively [3-5] (Schemes 1 and 2). Perimidine ring (peri-napthofused pyrimidine systems) is a heterocycle containing two nitrogen atoms which is the unusual system with an excess and deficiency of $p$-electrons simultaneously $[6,7]$. This feature makes them susceptible to electrophilic $[8,9]$ and nucleophilic attack [9]. The biological activities of perimidines have attracted our attention due to their wide range of application, for example, antitumor, antimicrobial, antifungal, and antiulcer [10-12]. Also, some of them were applied as coupler substances for preparation of oxidation dyestuffs, hair colouring compositions [13, 14], and fluorescent molecular sensors [15].
On the other side, ethyl aroylpyrovates $\mathbf{1 0}$ contain three different carbonyl groups with a different polarity and reactivity which condensed with various reagents to afford new heterocyclic compounds $[16,17]$. It was proven that the most reactive carbonyl is that adjacent to the ester group $[1,18]$ (Scheme 3).

From all the previous screening, the author was interested herein to investigate the reactivity of ethyl aroylpyrovate $\mathbf{1 0}$ in the reaction with 1,8-diaminonaphthalene and elucidate the product or products of such reaction. This due to the previous reaction can afford one or more of the seven products which will be illustrated (Scheme 4). Moreover, Gaussian09 computation software was considered to establish a well view about the reaction mechanism [19]. DFT/B3LYP is a suitable method for executing the optimization process [20] in the gas phase and ethanol solvent for comparative assertion. Essential parameters have been considered as heat during formation, frontier energy gap, dipole moment, and oscillator strength. Such parameters were intended due to their convinced impact in 


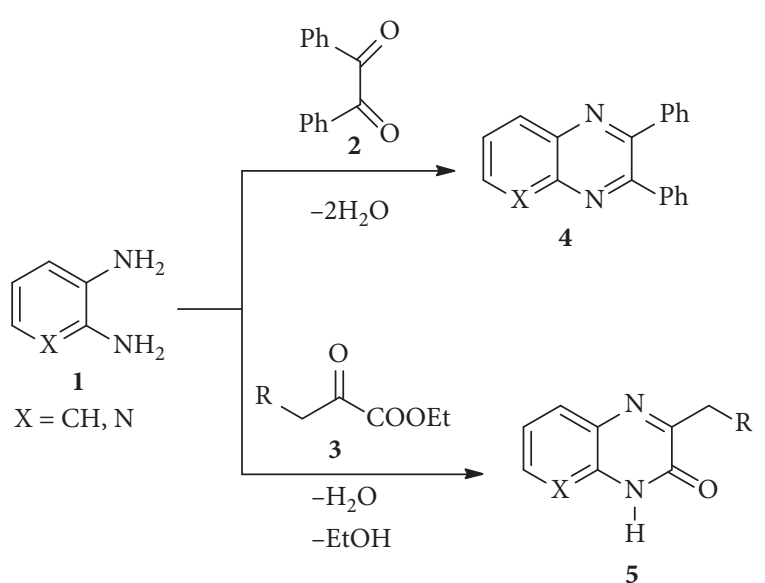

Scheme 1: Reaction of 1,2-diaminoaromatic compound 1 with dicarbonyl compounds 2 and 3 [1, 2].

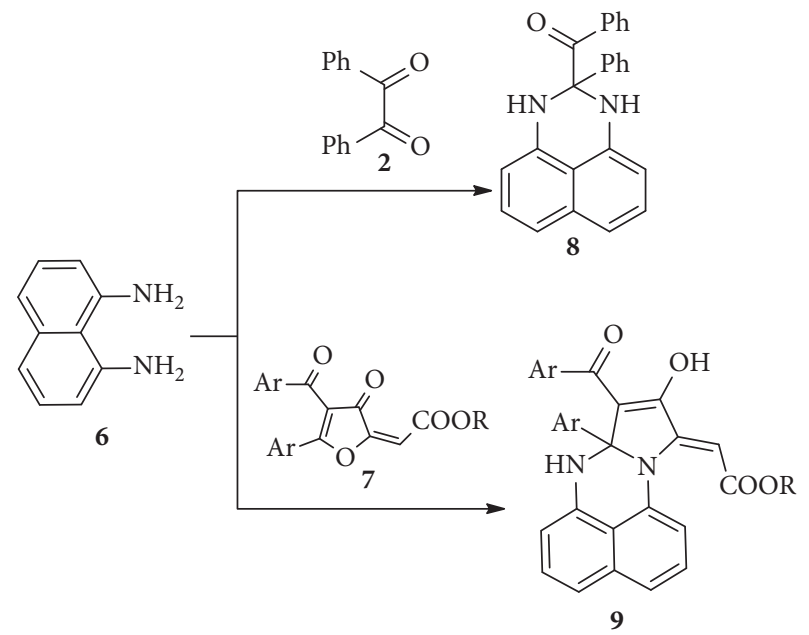

Scheme 2: Condensation of 1,8-diaminonaphthalene with benzyl 2 or alkyl carboxylate derivative of 3-furanone 7 [3-5].

stability differentiation between all possible outputs [21]. As well as investigating the antimicrobial activity for novel synthesized derivatives was also intended. The simulation procedure for antimicrobial behavior was also considered to strengthen the results.

\section{Experimental}

2.1. Physical Techniques. All melting points were uncorrected and measured on the Gallenkamp electric melting point apparatus (capillary method, Gallenkamp Co., London, UK). Infrared spectra were determined on a Mattson 5000 FT-IR spectrometer (Shimadzu Co., Kyoto, Japan, not all frequencies are reported) using $\mathrm{KBr}$ discs. The nuclear magnetic resonance NMR spectra were determined using a WP 300 spectrometer (Bruker Co., Billerica, MA, USA) at $300 \mathrm{MHz}$ for ${ }^{1} \mathrm{H}$ or $75.5 \mathrm{MHz}$ for ${ }^{13} \mathrm{C}$ using TMS as the internal standard. The mass spectra were recorded on a Qp2010 mass spectrometer (Shimadzu, Tokyo, Japan) at $70 \mathrm{eV}$ (EI mode). Elemental analyses $(\mathrm{C}, \mathrm{H}$, and $\mathrm{N}$ ) were determined on the PerkinElmer 2400 analyzer. The reactions were pursued by TLC (aluminum sheets, Merck), and the spots were disclosed by exposure to the UV lamp.

2.2. Synthesis of Ethyl 2-(2-Oxo-2-arylethyl)-2,3-dihydro-1Hperimidine-2-carboxylate $(\mathbf{1 2 a - e})$. In ethanolic solution, a mixture of 1,8-diaminonaphthalene $6(0.40 \mathrm{~g}, 2.5 \mathrm{mmol})$ and ethyl aroylpyrovate $\mathbf{1 0}(2.5 \mathrm{mmol})$ was refluxed for $5 \mathrm{hrs}$. The reaction mixture was allowed to cool at room temperature, and then, the solid formed was collected by filtration, dried, and recrystallized from ethanol.

2.2.1. Ethyl 2-(2-Oxo-2-phenylethyl)-2,3-dihydro-1H-perimidine2-carboxylate (12a). Dark red solid (yield, 70\%), m.p. = 190-192 $2^{\circ}$ C. IR (KBr) $\nu_{\max } 3435,3317(\mathrm{NH}), 1725,1628$ $(2 \mathrm{C}=\mathrm{O}) .{ }^{1} \mathrm{H}$ NMR $\left(\mathrm{DMSO}-d_{6}\right) \delta 1.33\left(t, J=7.2 \mathrm{~Hz}, 3 \mathrm{H}, \mathrm{CH}_{3}\right)$, $3.89\left(s, 2 \mathrm{H}, \mathrm{CH}_{2}\right), 4.32\left(q, J=7.2 \mathrm{~Hz}, 2 \mathrm{H}, \mathrm{CH}_{2}\right), 6.60-8.08$ ( $m, 11 \mathrm{H}, \mathrm{Ar}-\mathrm{H}), 10.80$ (brs, $2 \mathrm{H}, 2 \mathrm{NH}) ; \mathrm{MS}$ (EI): m/z (\%): 360 $\left(\mathrm{M}^{+}, 20\right), 347$ (25), $256(40), 170$ (20), and 92 (100). Analysis for $\mathrm{C}_{22} \mathrm{H}_{20} \mathrm{~N}_{2} \mathrm{O}_{3}$ (360.41): calcd: C, 73.32; H, 5.59; and N, 7.77\%. Found: C, 73.15; H, 5.39; and N, 7.60\%.

2.2.2. Ethyl 2-(2-Oxo-2-(p-tolyl)ethyl)-2,3-dihydro-1H-perimidine2-carboxylate (12b). Dark red solid (yield, 74\%), m.p. = $172-174^{\circ} \mathrm{C}$. IR (KBr) $\nu_{\max } 3443,3316(\mathrm{NH}), 1717,1610$ $(2 \mathrm{C}=\mathrm{O}) .{ }^{1} \mathrm{H}$ NMR $\left(\mathrm{DMSO}-d_{6}\right) \delta 1.33\left(t, J=7.0 \mathrm{~Hz}, 3 \mathrm{H}, \mathrm{CH}_{3}\right)$, $2.37\left(s, 3 \mathrm{H}, \mathrm{CH}_{3}\right), 3.87\left(s, 2 \mathrm{H}, \mathrm{CH}_{2}\right), 4.32(q, J=7.0 \mathrm{~Hz}, 2 \mathrm{H}$, $\mathrm{CH}_{2}$ ), 6.60-7.92 ( $\left.m, 10 \mathrm{H}, \mathrm{Ar}-\mathrm{H}\right), 10.89$ (brs, 2H, 2NH); MS (EI): $\mathrm{m} / \mathrm{z}(\%): 374\left(\mathrm{M}^{+}, 10\right), 350$ (60), 344 (100), $336(63), 328$ (38), 313 (52), 285 (28), 275 (25), 241 (18), and 134 (12). Analysis for $\mathrm{C}_{23} \mathrm{H}_{22} \mathrm{~N}_{2} \mathrm{O}_{3}$ (374.44): calcd: C, 73.78; $\mathrm{H}, 5.92$; and N, 7.48\%. Found: C, 73.59; H, 5.81; and N, 7.26\%.

2.2.3. Ethyl 2-(2-(4-Chlorophenyl)-2-oxoethyl)-2,3-dihydro$1 \mathrm{H}$-perimidine-2-carboxylate (12c). Dark red solid (yield, $68 \%)$, m.p. $=180-182^{\circ} \mathrm{C} . \mathrm{IR}(\mathrm{KBr}) v_{\max } 3434,3316(\mathrm{NH})$, $1716,1627(2 \mathrm{C}=\mathrm{O}) .{ }^{1} \mathrm{H}$ NMR $\left(\mathrm{DMSO}-d_{6}\right) \delta 1.32(t, J=7.0 \mathrm{~Hz}$, $\left.3 \mathrm{H}, \mathrm{CH}_{3}\right), 3.86\left(s, 2 \mathrm{H}, \mathrm{CH}_{2}\right), 4.33\left(q, J=7.0 \mathrm{~Hz}, 2 \mathrm{H}, \mathrm{CH}_{2}\right)$, 6.49-7.98 ( $m, 10 \mathrm{H}$, Ar-H), 10.82 (brs, 2H, 2NH); MS (EI): $\mathrm{m} / \mathrm{z}(\%): 396\left(\mathrm{M}^{+}+2,10\right), 395\left(\mathrm{M}^{+}+1,11\right), 394\left(\mathrm{M}^{+}, 25\right), 361$ (26), 347 (28), 319 (52), 277 (75), 257 (100), 111 (14), 105 (54), and 91 (32). Analysis for $\mathrm{C}_{22} \mathrm{H}_{19} \mathrm{ClN}_{2} \mathrm{O}_{3}$ (394.85): calcd: C, 66.92; H, 4.85; and N, 7.09\%. Found: C, 66.78; H, 4.74; and $\mathrm{N}, 6.89 \%$.

2.2.4. Ethyl 2-(2-(4-Fluorophenyl)-2-oxoethyl)-2,3-dihydro1H-perimidine-2-carboxylate (12d). Dark red solid (yield, $73 \%)$, m.p. $=168-170^{\circ} \mathrm{C} . \mathrm{IR}(\mathrm{KBr}) v_{\max } 3429$ (br. NH), 1671, $1610(2 \mathrm{C}=\mathrm{O}) .{ }^{1} \mathrm{H}$ NMR (DMSO- $\left.d_{6}\right) \delta 1.22(t, J=7.0 \mathrm{~Hz}, 3 \mathrm{H}$, $\left.\mathrm{CH}_{3}\right), 3.13\left(s, 2 \mathrm{H}, \mathrm{CH}_{2}\right), 3.67\left(q, J=7.0 \mathrm{~Hz}, 2 \mathrm{H}, \mathrm{CH}_{2}\right)$, 6.29-8.04 ( $m, 10 \mathrm{H}, \mathrm{Ar}-\mathrm{H}), 10.50$ (brs, $2 \mathrm{H}, 2 \mathrm{NH}) ;{ }^{13} \mathrm{C} \mathrm{NMR}$ $\left(\mathrm{DMSO}-d_{6}\right) \delta 11.91\left(\mathrm{CH}_{3}\right), 35.4\left(\mathrm{CH}_{2}\right), 42.69\left(\mathrm{CH}_{2}\right), 100.42$ (C2), [113.85, 115.26, 115.55, 118.25, 119.33, 120.57, 122.49, $127.63,128.41,130.42,133.46,135.16,148.63,149.05$ (ArC)], $163.20(\mathrm{C}=\mathrm{O}), 196.23(\mathrm{C}=\mathrm{O})$. MS (EI): $\mathrm{m} / \mathrm{z}(\%): 378$ $\left(\mathrm{M}^{+}, 12\right), 377\left(\mathrm{M}^{+}-1,3.4\right), 367$ (28), 360 (22), 348 (6), 336 


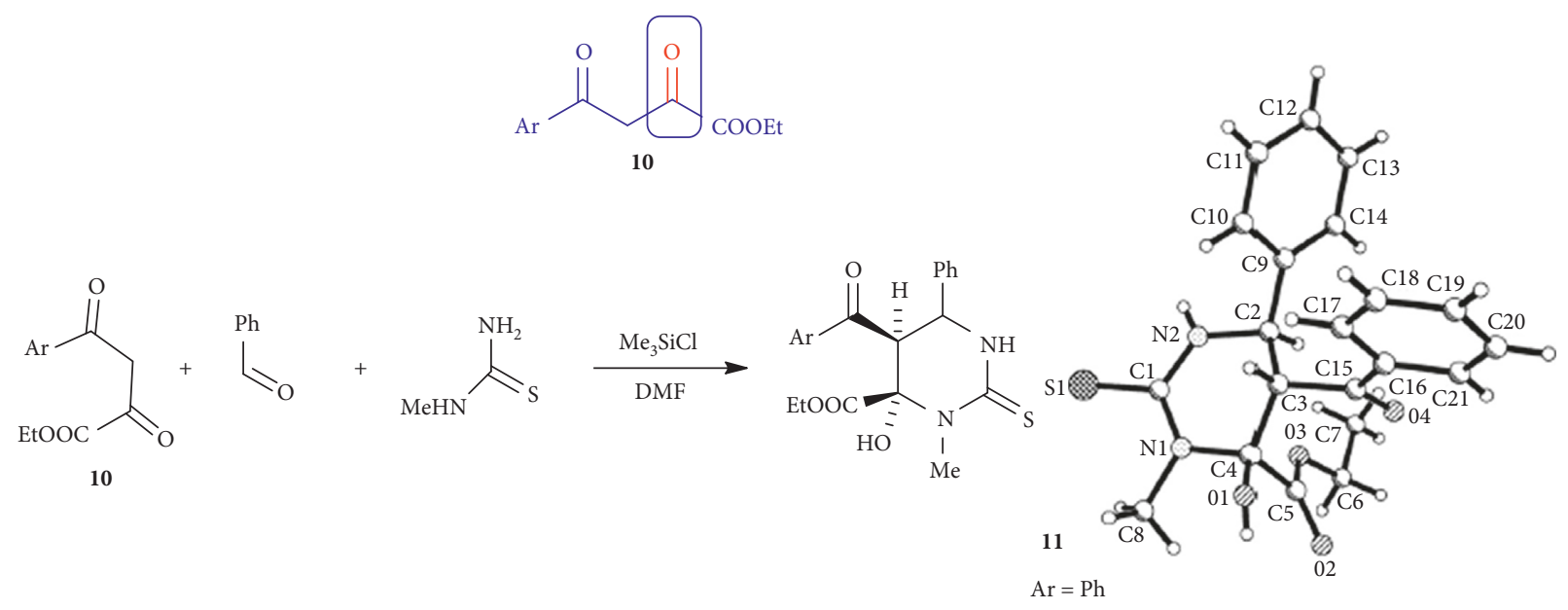

Scheme 3: The X-ray analyses which prove the reactivity of carbonyl group-2 of ethyl aroylpyrovate $\mathbf{1 0}[1,18]$.

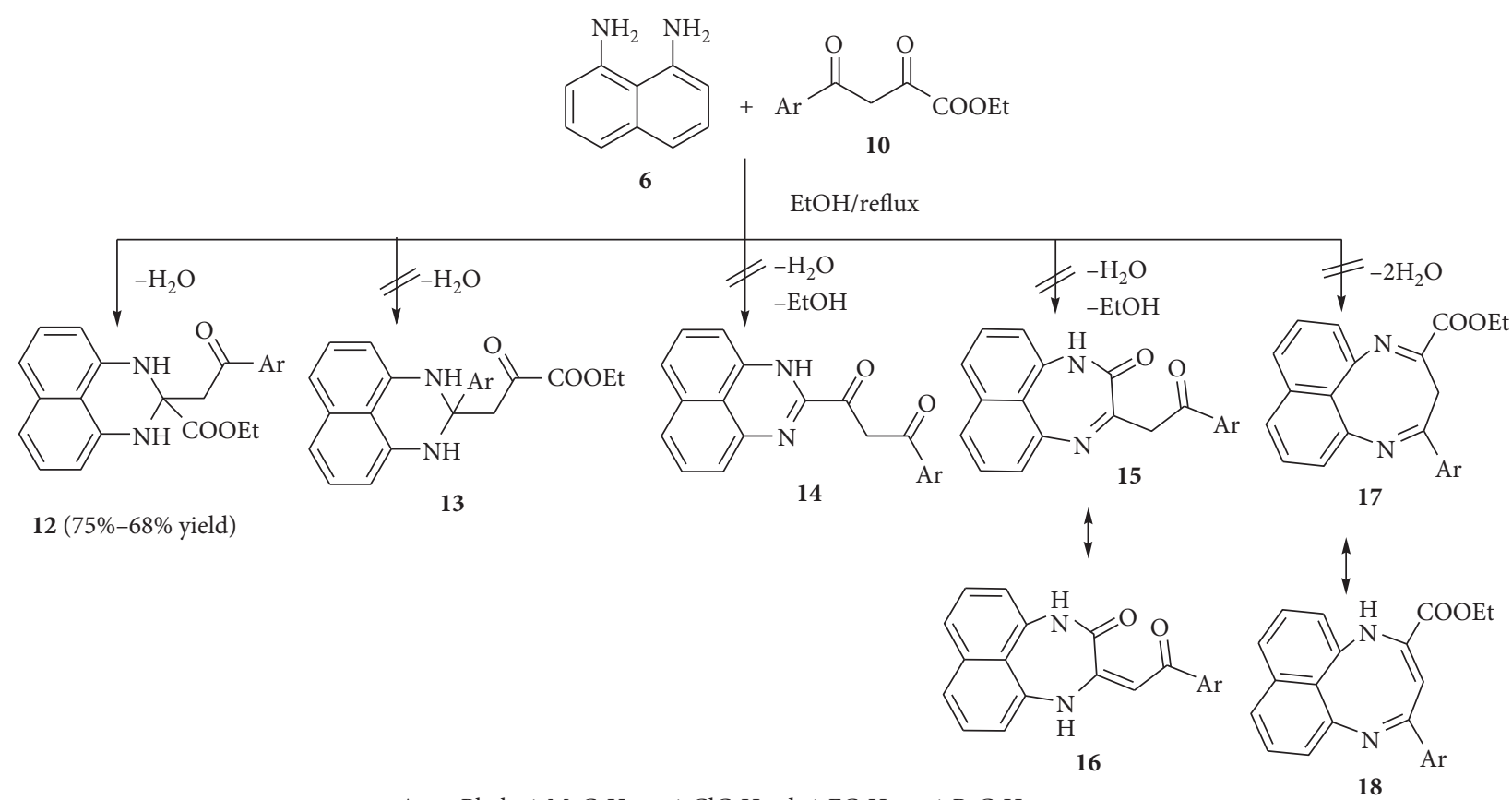

Ar: a, $\mathrm{Ph} ; \mathrm{b}, 4-\mathrm{MeC}_{6} \mathrm{H}_{4} ; \mathrm{c}, 4-\mathrm{ClC}_{6} \mathrm{H}_{4} ; \mathrm{d}, 4-\mathrm{FC}_{6} \mathrm{H}_{4} ; \mathrm{e}, 4-\mathrm{BrC}_{6} \mathrm{H}_{4}$

Scheme 4: Reaction of 1,8-diaminonaphthalene $\mathbf{6}$ with ethyl aroylpyrovate derivatives 10a-e.

(27), 332 (12), 304 (14), 168 (2.4), 156 (1.1), 122 (2.3), 93 (27), 92 (23), and 77 (45). Analysis for $\mathrm{C}_{22} \mathrm{H}_{19} \mathrm{FN}_{2} \mathrm{O}_{3}(378.40)$ : calcd: C, 69.83; H, 5.06; and N, 7.40\%. Found: C, 69.61; H, 4.94; and $\mathrm{N}, 7.52 \%$.

2.2.5. Ethyl 2-(2-(4-Bromophenyl)-2-oxoethyl)-2,3-dihydro1H-perimidine-2-carboxylate (12e). Dark red solid (yield, $75 \%)$, m.p. $=175-176^{\circ} \mathrm{C} . \mathrm{IR}(\mathrm{KBr}) v_{\max } 3442,3318(\mathrm{NH})$, $1717,1627(2 \mathrm{C}=\mathrm{O}) .{ }^{1} \mathrm{H}$ NMR (DMSO- $\left.d_{6}\right) \delta 1.33(t, J=$ $\left.7.0 \mathrm{~Hz}, 3 \mathrm{H}, \mathrm{CH}_{3}\right), 3.87\left(s, 2 \mathrm{H}, \mathrm{CH}_{2}\right), 4.34(q, J=7.0 \mathrm{~Hz}, 2 \mathrm{H}$, $\mathrm{CH}_{2}$ ), 6.47-7.99 ( $\left.m, 10 \mathrm{H}, \mathrm{Ar}-\mathrm{H}\right), 10.91$ (brs, 2H, 2NH); MS (EI): $\mathrm{m} / \mathrm{z}(\%): 441\left(\mathrm{M}^{+}+2,1.8\right), 440\left(\mathrm{M}^{+}+1,12\right), 439\left(\mathrm{M}^{+}, 3\right)$, 424 (34), 412 (23), 392 (14), 381 (100), 380 (23), and 154 (1.1).
Analysis for $\mathrm{C}_{22} \mathrm{H}_{19} \mathrm{BrN}_{2} \mathrm{O}_{3}$ (439.31): calcd: C, 60.15; $\mathrm{H}, 4.36$; and N, 6.38\%. Found: C, 60.03; H, 4.27; and N, 6.19\%.

2.3. Coupling Reaction of Compounds 12a-e to Synthesize Perimidine Derivatives $\mathbf{2 1 a - e . ~ T o ~ a ~ s t i r r e d ~ s o l u t i o n ~ o f ~}$ ethyl 2-(2-aryl-2-oxoethyl)-2,3-dihydro-1H-perimidine-2carboxylate derivatives 12a-e (1 mmole) in ethanol, sodium hydroxide solution $(0.04 \mathrm{~g}$ of $\mathrm{NaOH}$ in $15 \mathrm{~mL}$ ethanol with two drops of water), was added and the reaction mixture was cooled in an ice bath to $0-5^{\circ} \mathrm{C}$. To the resulting solution, while being stirred, was added dropwise over a period of $10 \mathrm{~min}$ a solution of aniline diazonium chloride, prepared as usual by diazotizing aniline ( 1 mmole) in 
hydrochloric acid $(6 \mathrm{M}, 1 \mathrm{~mL})$ with sodium nitrite $(1 \mathrm{M}$, $1 \mathrm{~mL}$ ). The whole mixture was then left in a refrigerator overnight. The precipitated solid was filtered, washed with water, and finally crystallized from ethanol/dioxane to give the respective hydrazone derivatives 21 a-e.

2.3.1. 2-[N-Phenyl-2-oxo-2-phenyl-ethanehydrazonoyl]-1Hperimidine (21a). Dark brown solid (yield 76\%), m.p. $>300^{\circ} \mathrm{C}$ [22], IR $v$ : br $3427(2 \mathrm{NH}), 1623(\mathrm{CO}) \mathrm{cm}^{-1},{ }^{1} \mathrm{H}$ NMR $\left(\right.$ DMSO- $\left._{6}\right) \delta: 6.72-7.80(m, 16 \mathrm{H}, \mathrm{Ar}-\mathrm{H}), 13.62(s, 2 \mathrm{H}$, 2NH); MS m/z (\%) $390\left(\mathrm{M}^{+}, 5\right), 314\left(\mathrm{M}^{+}-\mathrm{Ph}, 35\right), 298\left(\mathrm{M}^{+}-\right.$ $\mathrm{PhNH}, 23), 285\left(\mathrm{M}^{+}-\mathrm{PhCO}, 6\right), 167\left(\mathrm{C}_{11} \mathrm{H}_{7} \mathrm{~N}_{2}, 5\right), 139$ (12), 127 (5), 105 (5), 93 (5), and 84 (12). Analysis for $\mathrm{C}_{25} \mathrm{H}_{18} \mathrm{~N}_{4} \mathrm{O}$ (390.45): calcd: C, 76.91; H, 4.65; and N, 14.35\%. Found: C, 76.74; $\mathrm{H}, 4.46$; and $\mathrm{N}, 14.09 \%$.

2.3.2. 2-[N-Phenyl-2-oxo-2-(4-methyl)phenyl-ethanehydrazonoyl]1 H-perimidine (21b). Dark brown solid (yield 69\%), m.p. = $162-164^{\circ} \mathrm{C},{ }^{1} \mathrm{H}$ NMR (DMSO-d $\left.{ }_{6}\right) \delta: 2.28\left(\mathrm{~s}, 3 \mathrm{H}, \mathrm{CH}_{3}\right)$, 7.40-8.35 (m, 15H, Ar-H), 10.90 (s, 2H, 2NH); MS m/z (\%) $404\left(\mathrm{M}^{+}, 15\right), 403\left(\mathrm{M}^{+}-1,21\right), 388\left(\mathrm{M}^{+}-\mathrm{CH}_{3}, 39\right), 330$ $\left(\mathrm{M}^{+}-\mathrm{C}_{3} \mathrm{H}_{5} \mathrm{O}_{2}, 74\right), 310$ (43), 298 (100), 266 (24), 165 (6), 148 (5), 121 (13), 118 (12), and 91 (4). Analysis for $\mathrm{C}_{26} \mathrm{H}_{20} \mathrm{~N}_{4} \mathrm{O}$ (404.47): calcd: C, $77.21 ; \mathrm{H}, 4.98$; and N, 13.85\%. Found: C, 76.94; H, 4.76; and N, $13.66 \%$.

2.3.3. 3-[N-Phenyl-2-oxo-2-(4-chloro)phenyl-ethanehydrazonoyl]1H-perimidine (21c). Dark brown solid (yield 68\%), m.p. $=150-152^{\circ} \mathrm{C}$, IR $v$ : $3386,3184(2 \mathrm{NH}), 1644(\mathrm{CO}) \mathrm{cm}^{-1},{ }^{1} \mathrm{H}$ NMR (DMSO-d $\left.\mathrm{d}_{6}\right) \delta: 7.05-8.39(\mathrm{~m}, 15 \mathrm{H}, \mathrm{Ar}-\mathrm{H}), 13.45(\mathrm{~s}, 2 \mathrm{H}$, 2NH); MS m/z (\%) $424\left(\mathrm{M}^{+}, 10\right), 387$ (21), 369 (100), 336 (65), 313 (32), 308 (45), 299 (63), 284 (64), 111 (7), 87 (22), and 71 (33). Analysis for $\mathrm{C}_{25} \mathrm{H}_{17} \mathrm{ClN}_{4} \mathrm{O}$ (424.89): calcd: $\mathrm{C}$, 70.67; H, 4.03; and N, 13.19\%. Found: C, 70.54; H, 3.89; and $\mathrm{N}, 13.36 \%$.

2.3.4. 2-[N-Phenyl-2-oxo-2-(4-fluoro)phenyl-ethanehydrazonoyl]1H-perimidine (21d). Dark brown solid (yield 70\%), m.p. $=157-159^{\circ} \mathrm{C}$, IR $v$ : br $3436(2 \mathrm{NH}), 1630(\mathrm{CO}) \mathrm{cm}^{-1},{ }^{1} \mathrm{H}$ NMR (DMSO- $\mathrm{d}_{6}$ ) $\delta: 6.80-8.37(m, 15 \mathrm{H}, \mathrm{Ar}-\mathrm{H}), 12.60(s, 2 \mathrm{H}, 2 \mathrm{NH})$; MS m/z (\%) 408 (M+ 22), 371 (62), 305 (24), 269 (17), 252 (12), 169 (8), 165 (6), 134 (12), 106 (11), 95 (2), 84 (33), and 65 (100). Analysis for $\mathrm{C}_{25} \mathrm{H}_{17} \mathrm{FN}_{4} \mathrm{O}$ (408.44): calcd: $\mathrm{C}$, 73.52; $\mathrm{H}, 4.20$; and $\mathrm{N}, 13.72 \%$. Found: $\mathrm{C}, 73.33 ; \mathrm{H}, 4.05$; and $\mathrm{N}$, $13.65 \%$.

2.3.5. 2-[N-Phenyl-2-oxo-2-(4-bromo)phenyl-ethanehydrazonoyl]1H-perimidine (21e). Dark brown solid (yield 63\%), m.p. $>300^{\circ} \mathrm{C}$, IR $v$ : 3375,3225 (2NH), 1620 (CO) $\mathrm{cm}^{-1},{ }_{1}^{1} \mathrm{H}$ NMR $\left(\right.$ DMSO-d $\left._{6}\right) \delta: 7.27-8.10(\mathrm{~m}, 15 \mathrm{H}, \mathrm{Ar}-\mathrm{H}), 10.91(\mathrm{~s}, 1 \mathrm{H}$, $1 \mathrm{NH}), 12.95$ (s, 1H, NH); MS m/z (\%) $470\left(\mathrm{M}^{+}+1,12\right), 468$ $\left(\mathrm{M}^{+}-1,7\right), 450(16), 426$ (22), 384 (59), 365 (59), 155 (2.3), 76 (6), and 65 (13). Analysis for $\mathrm{C}_{25} \mathrm{H}_{17} \mathrm{BrN}_{4} \mathrm{O}$ (469.34): calcd: C, 63.98; H, 3.65; and N, 11.94\%. Found: C, 63.78; H, 3.56; and $\mathrm{N}, 11.69 \%$.

\subsection{Theoretical Implementation}

2.4.1. Geometrical Optimization. Gaussian09 program [19] is software used to investigate all the proposed structures 12-18 and $21(\mathrm{Ar}=\mathrm{Ph})$. DFT/B3LYP method is a suitable method used to investigate the physicochemical properties of proposed tautomeric forms. 3-21G is the base set used to accomplish the comparative investigation. Essential files yielded from this implementation (log and chk files). These files were visualized over the program screen to extract important parameters. HOMO and LUMO images were also obtained. Other additive energies according to optimized structures applying HyperChem 8.1 program were computed. Molecular mechanics $\left(\mathrm{MM}^{+}\right)$method was followed by semiempirical AM1 one to extract log files. All parameters were obtained after reaching to the equilibrium state in the gas phase.

2.4.2. Molecular Docking. Utilization for AutoDock tools 4.2 was to execute the docking process between the proposed drug and protein receptors of variable bacteria and fungi. Aspergillus niger (1ukc), Bacillis subtilis (1ydo), Escherichia coli (5o22), Geotrichum candidum (1thg), Klebsiella pneumoniae (3gdz), Pseudomonas aeruginosa (2w7q), Salmonella typhimurium (1af7), Staphylococcus aureus (1bqb), Staphylococcus epidermidis (3kp3), and Streptococcus pyogenes (2esr) were the microorganism protein receptors used in this investigation. Such process was accomplished after the addition of Gasteiger charges over all compound atoms. The nonpolar atoms of hydrogen were incorporated to effect on the multiplication of rotatable bonds. The presence of hydrogen atoms with Kollman unite charge type is an essential preliminary feature [23]. The affinity maps by $x \times \AA$ grid points with $0.375 \AA$ spacing were adapted using the Autogrid program [24]. Electrostatic terms and Vander Waals force were evaluated after adapting the Autodock parameter sets and the dielectric function of distance dependent, respectively. The docking simulation process to be the completed Lamarckian genetic algorithm (LGA) and the Solis and Wets local search method must be used [25]. The torsion of the investigated compound and occasionally the initial position as well as the orientation must be set. The rotatable torsions must be released completely through the docking process. Each docking process was accomplished through tens following runs and adjusted to be block after reaching 250000 energy considerations. Throughout the process, the size was settled to be 150 , a translational step of $0.2 \AA$, and quaternion and torsion steps were of 5 .

\section{Results and Discussion}

3.1. Chemistry. Scheme 4 illustrates all possible products 12-18 from the reaction of 1,8-diaminonaphthalene 6 and ethyl aroylpyrovate $\mathbf{1 0}$ in refluxing ethanol. Such possibilities were tested using Gaussian 09 software to optimize their structural forms (Figure 1) and computed essential parameters. These parameters are significant in asserting the reaction mechanism built on experimental aspects. The TLC experiment and the spectral data $\left({ }^{1} \mathrm{H},{ }^{13} \mathrm{C}\right.$ NMR, mass, and IR) of the products indicate the isolation of only one product 


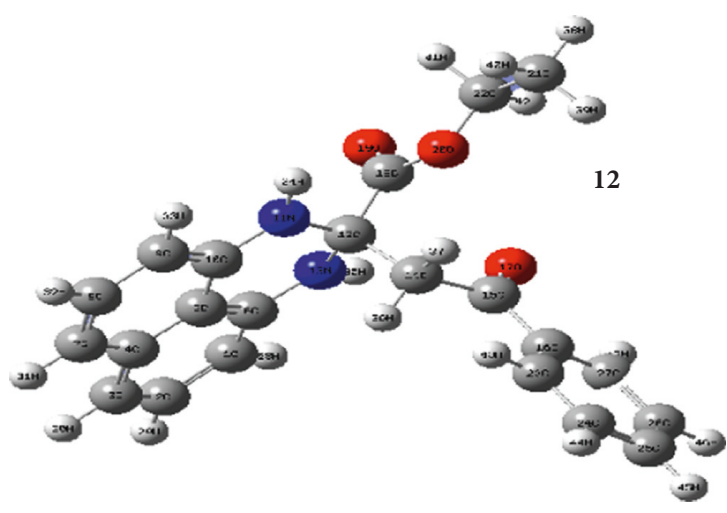

(a)

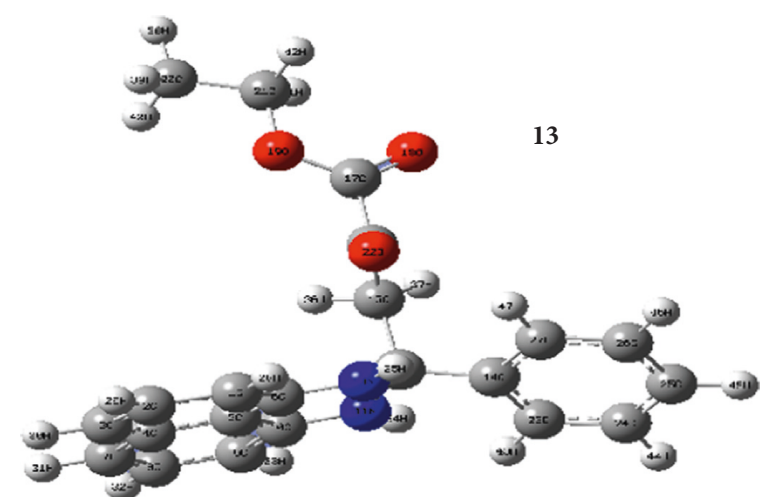

(b)

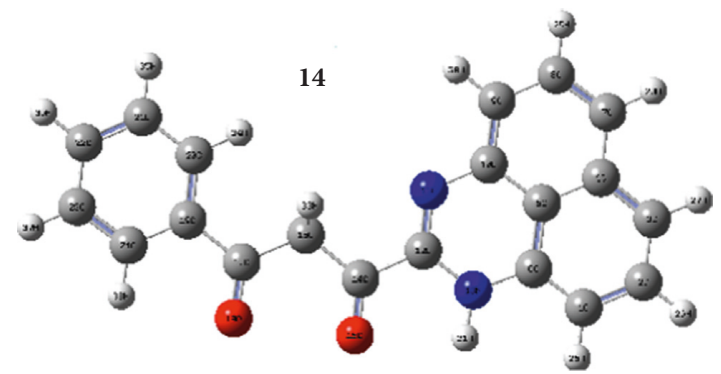

(c)

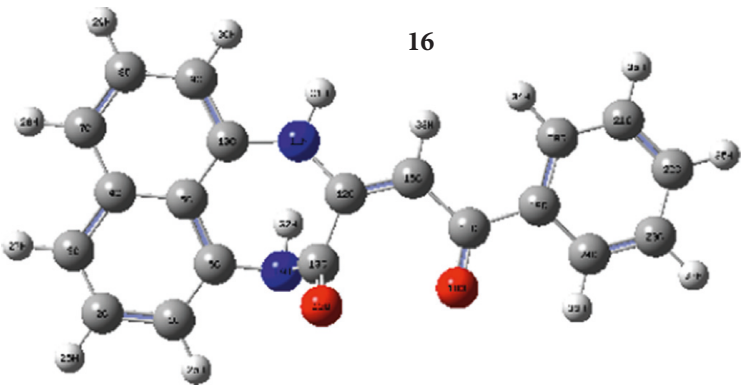

(e)

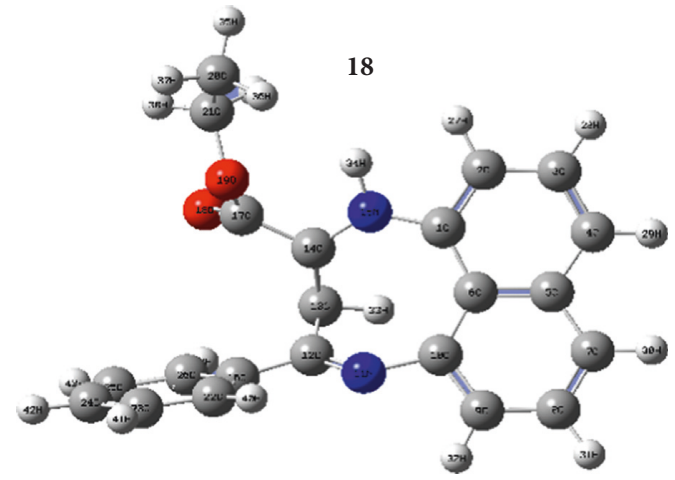

(g)

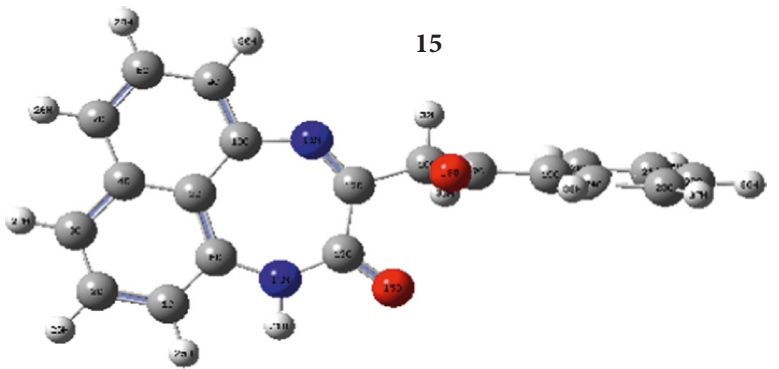

(d)

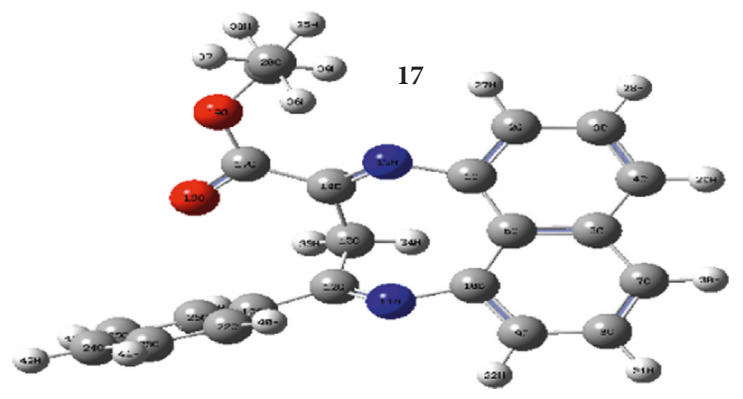

(f)

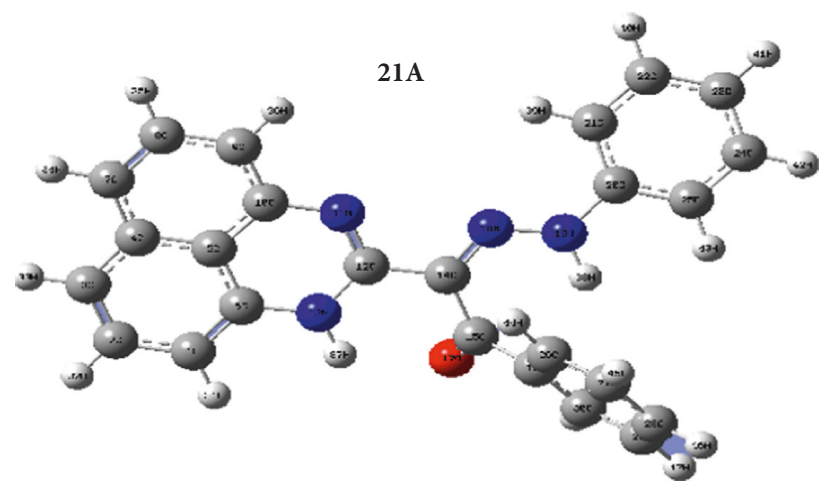

(h)

Figure 1: Continued. 


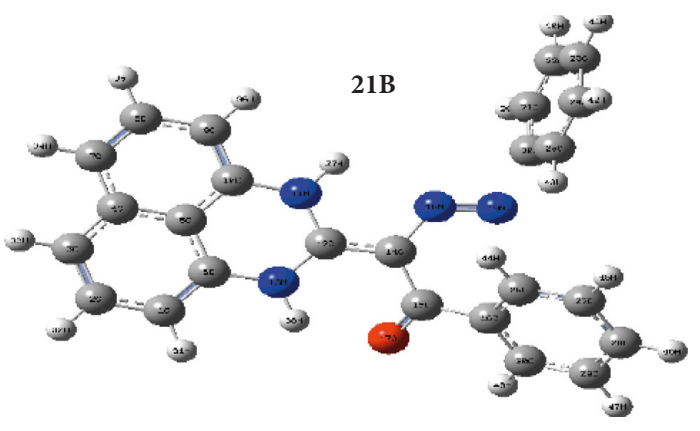

(i)

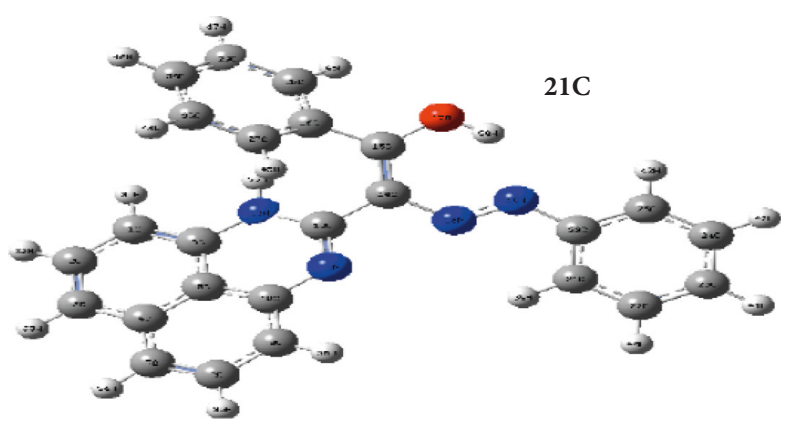

(j)

FIgURE 1: The optimized geometries of all suggested derivatives (a-g) $\mathbf{1 2 - 1 8}$ and $(\mathrm{h}-\mathrm{j}) \mathbf{2 1} \mathbf{A}-\mathbf{C}$.

in each case for such reaction. Their mass spectra show the molecular ion peak corresponding to elimination of only one water molecule which matches strongly with both structures 12 or 13. Structure 13 was ruled out based on the data of IR and ${ }^{13} \mathrm{C}$ NMR spectra. This is due to the presence of two absorption bands for the two carbonyl groups characteristic for ester and aroyl groups at 1725-1716 and $1628-1610 \mathrm{~cm}^{-1}$. The low value of the second carbonyl group can be attributed to the conjugation with aryl moiety and the hydrogen bond with the NH group. Moreover, all ${ }^{1} \mathrm{H}$ NMR spectra of the products $12 \mathbf{a}-\mathbf{e}$ revealed the presence of triplet and quartet signals for $\mathrm{CH}_{3} \mathrm{CH}_{2}$ integral ester groups near 1.33 and $4.32 \mathrm{ppm}$. As well as, the singlet signal for the $\mathrm{CH}_{2}$ group was found near $3.87 \mathrm{ppm}$ (see Experimental). Another evidence for the structures $12 \mathrm{a}-\mathbf{e}$ is the value of $\mathrm{C} 2$ concerning to the perimidine ring in the ${ }^{13} \mathrm{C}$ NMR spectrum of compound $\mathbf{1 2 d}$ (as an example for series prepared). Such was appeared at down field $(\delta=100.42 \mathrm{ppm})$ due to the presence of electron withdrawing ester group at the same carbon. However, the C2 in structure 13 appeared at the up-field value near $\delta=$ $81.8 \mathrm{ppm}$ [5]. All previous concerns were assured from optimizing characteristic parameters executed from the DFT/B3LYP method (Table 1). 3-21G base set leads to produce best distribution for atomic contents of each compound in the gas phase and ethanol. The reduced formation energy values for compounds 12 and $\mathbf{1 3}$ point to the truth of the oriented mechanism proposed. The excellence for the formation energy value of compound $\mathbf{1 2}$ propose its priority as the only one product yielded from the condensation reaction. The high value of dipole moment of such compound (12) is suitable for the high difference in electronegativity inside the compound. Moreover, the reduced oscillator strength of such compound is suitable for facilitated electronic transition inside the compound (12) which coincides with its reactivity. This proposal was also confirmed by applying HyperChem 8.1 program which provides data (Table 2) and confirms the previous aspects. The reduced content energies (total energy, binding energy, and heat during formation) of compound $\mathbf{1 2}$ in comparing with others (13-18) confirm its high stability. This leads to its prior in production without conflict.

In continuation, the reactivity of the active methylene group in ethyl 2-(2-aryl-2-oxoethyl)-2,3-dihydro- $1 \mathrm{H}$ perimidine-2-carboxylate $(\mathbf{1 2 a}-\mathbf{e})$ toward the coupling reaction with diazotized aniline in ethanol in the presence of
$\mathrm{NaOH}$ has been investigated as shown in Scheme 5. Mass, IR, ${ }^{1} \mathrm{H}$ NMR, and elemental analyses confirmed the chemical structure of coupling products as the structure 21a-e. The disappearance of the carbonyl absorption band of the ester group in all IR spectra of all derivatives (21a-e) proved that the coupling reaction proceeds via the Japp-Klingemann reaction [26] with elimination of the ethyl format molecule (Scheme 5). The actual tautomeric structure of the coupling products 21A-C was studied and confirmed based on computational data extracted. The minimized internal energies (total energy and binding energy) beside the formation energy (Tables 1 and 2) of $\mathbf{2 1}$ tautomers suggest their high stability which outweigh their production from the coupling reaction and indicate that the most stable tautomer is $21 \mathbf{A}$. The HOMO and LUMO levels (Figures 2 and 3) were extracted over the optimized structures for comparison. The HOMO level appeared is very concentrated in the compounds over 1,8-diaminonaphthalene moiety of the perimidine ring in 21. However, the LUMO level appeared is concentrated in the Ar-CO moiety which considered a good receptor for electrons as appeared in the coupling reaction. The two levels have the same positions in the coupling products (21a-e) which verify the same electron density attitude after reaction.

3.2. Biological Activity. The agar diffusion technique was used in screening the antimicrobial activity of all derivatives 12a-e and 21a-e [27] against two fungi, namely, A. Niger and $G$. candidum in comparison with Amphotericin $B$ as a reference drug. Four species of each of Gram-positive and Gram-negative bacteria were tested against standard antibacterial agents as ampicillin and gentamicin, respectively (Tables 3 and 4). A suspension solution of the organisms was added to the sterile nutrient agar media at $45^{\circ} \mathrm{C}$, and the mixture was transferred to sterile Petri dishes and allowed to solidify. Holes of $6 \mathrm{~mm}$ in diameter were made using a cork borer. A solution of each perimidines $12 \mathbf{a}-\mathbf{e}$ or $21 \mathbf{a}-\mathbf{e}$ or the reference drugs $(5 \mathrm{mg} / \mathrm{mL})$ in dimethylsulfoxide (DMSO) was prepared. The amount tested of either the synthesized compounds or reference drugs was $100 \mu \mathrm{L}$. Dimethylsulfoxide (DMSO) was used as a negative control. The plates were left for $1 \mathrm{~h}$ at room temperature as a period of preincubation diffusion to minimize the effects of variation in time between the applications of different solutions. 


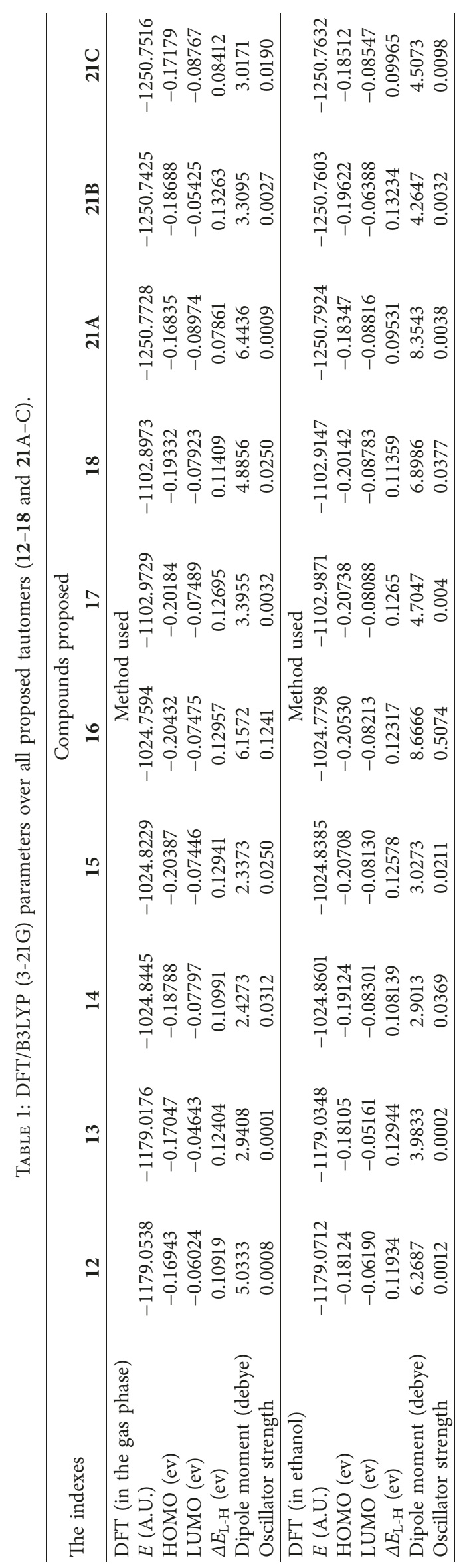




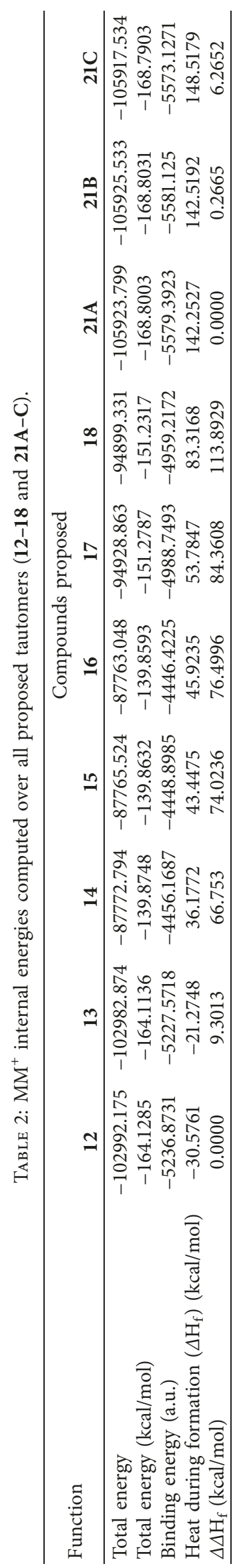



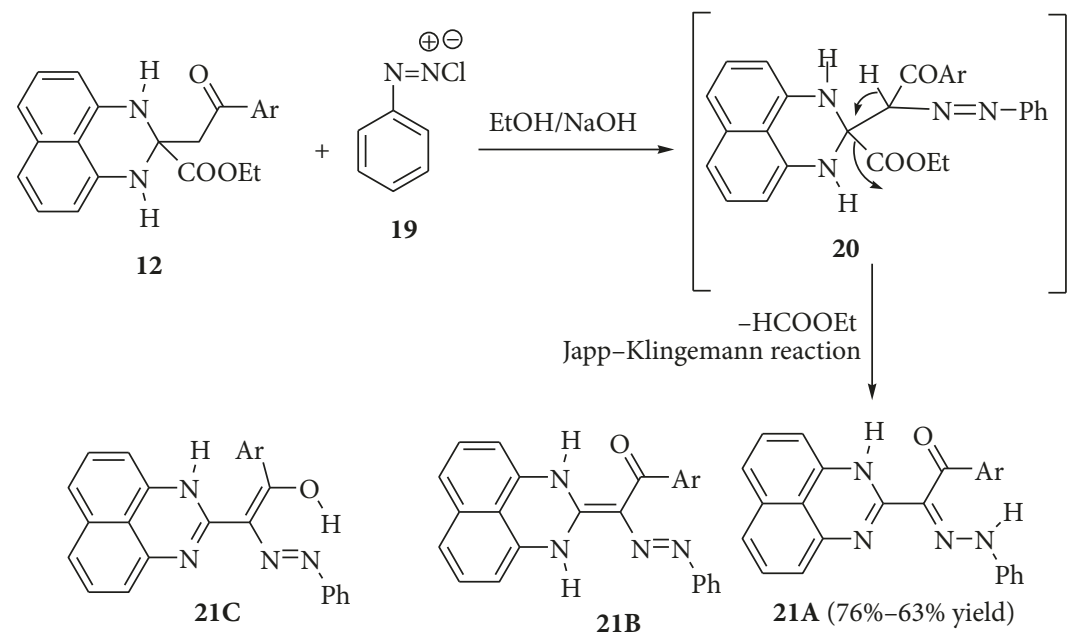

Ar: a, Ph; b, 4- $-\mathrm{MeC}_{6} \mathrm{H}_{4} ; \mathrm{c}, 4-\mathrm{ClC}_{6} \mathrm{H}_{4} ; \mathrm{d}, 4-\mathrm{FC}_{6} \mathrm{H}_{4} ; \mathrm{e}, 4-\mathrm{BrC}_{6} \mathrm{H}_{4}$

Scheme 5: Coupling reaction of compounds 12a-e.

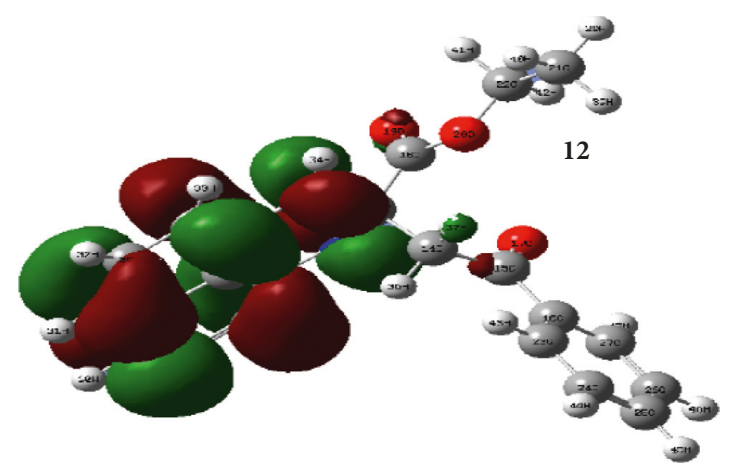

(a)

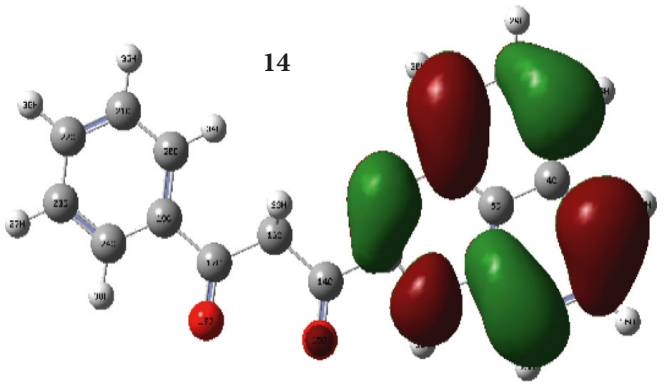

(c)

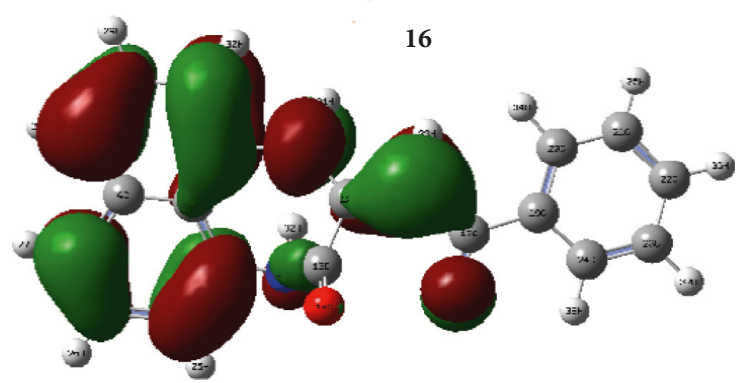

(e)

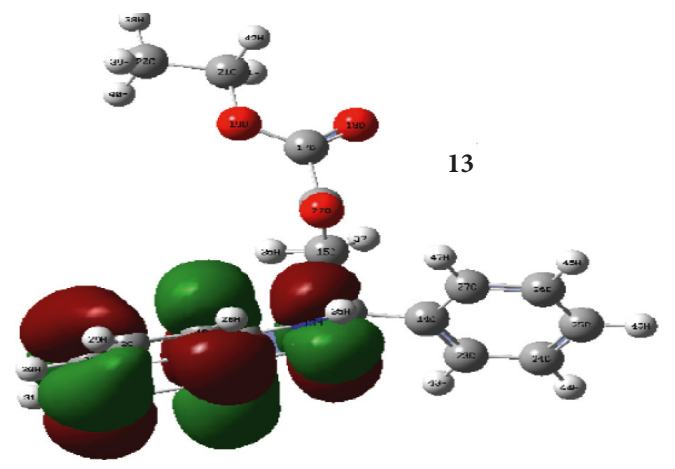

(b)

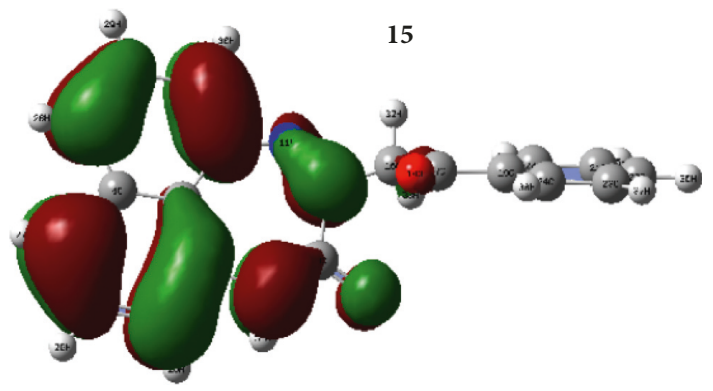

(d)

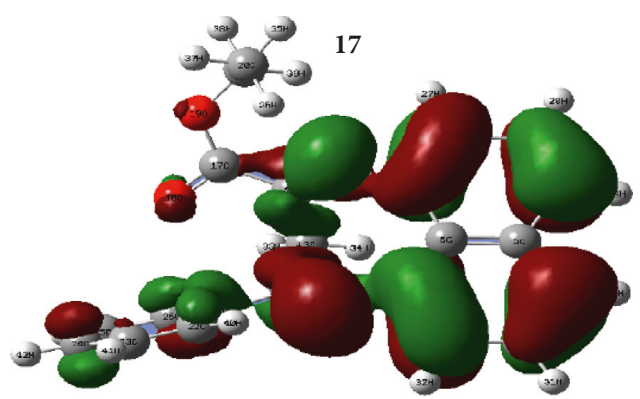

(f)

Figure 2: Continued. 


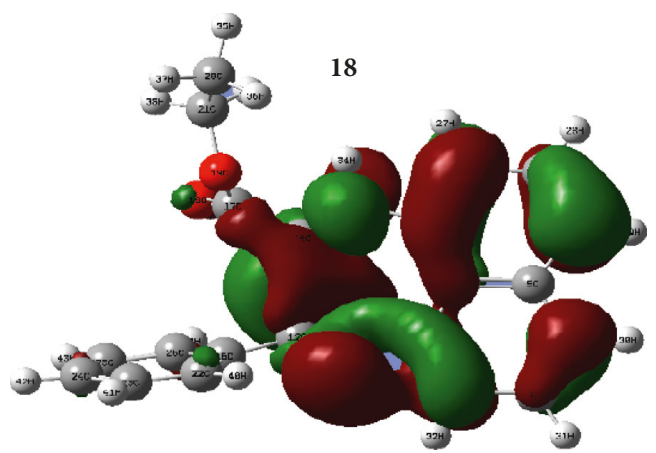

(g)

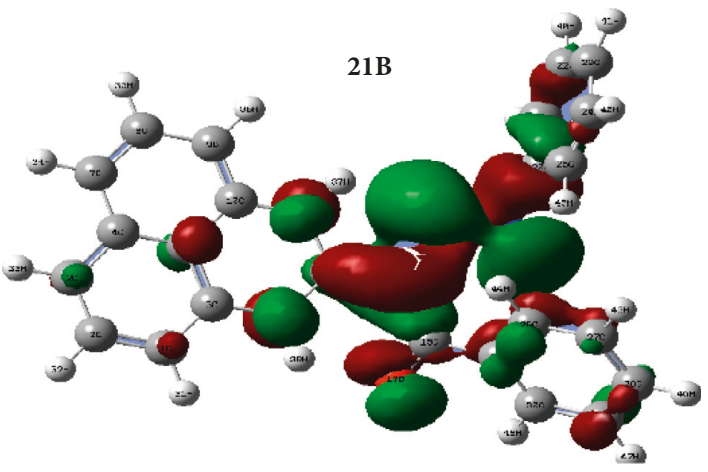

(i)

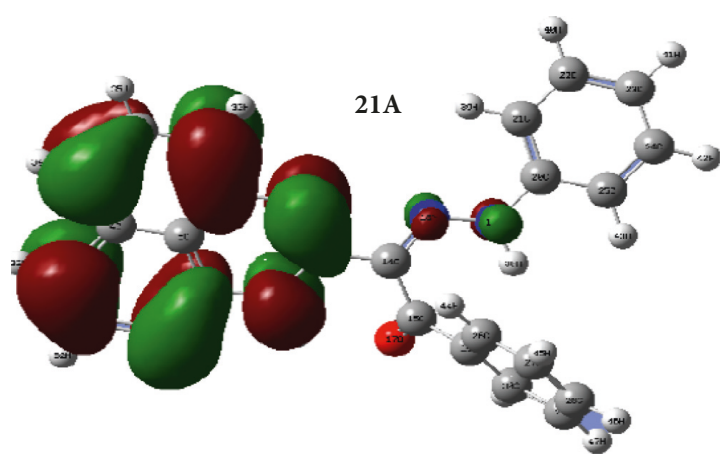

(h)

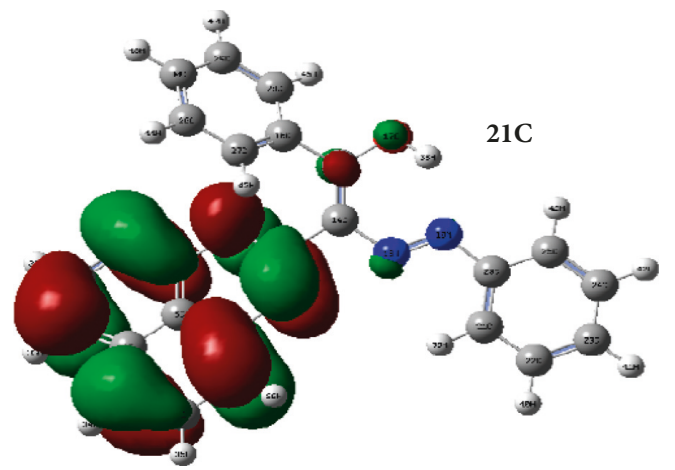

(j)

FIgURE 2: (a-j) Frontier orbitals regarding the HOMO level for optimized structures.

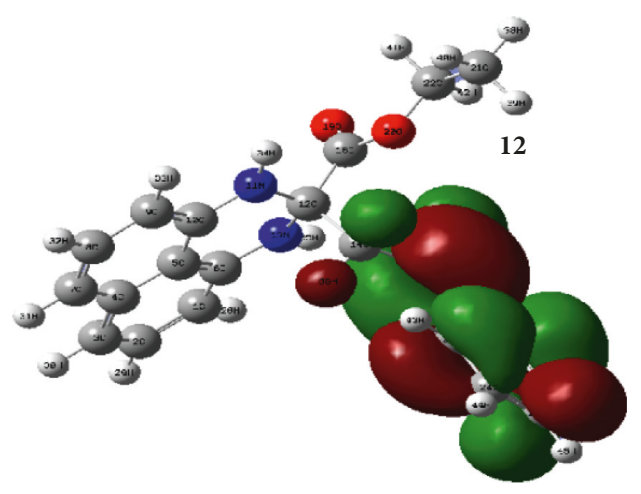

(a)

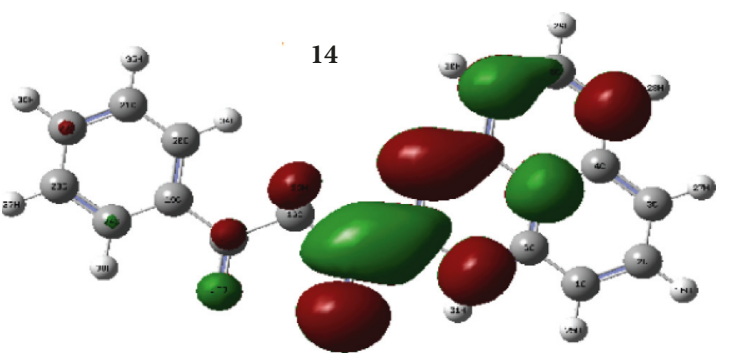

(c)

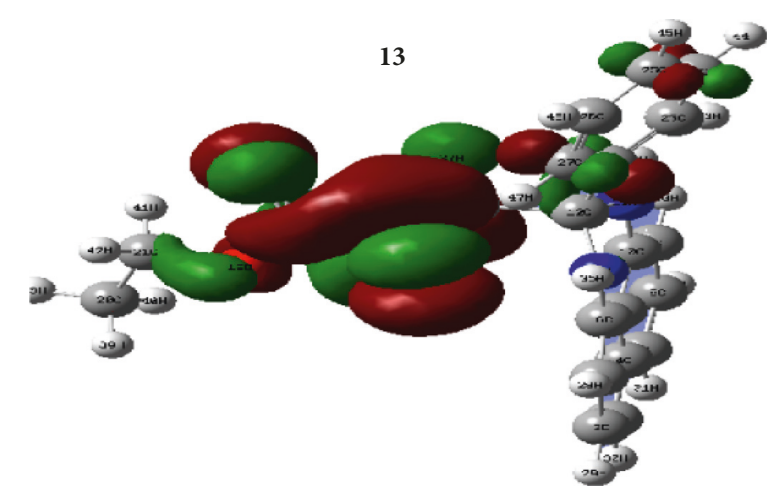

(b)

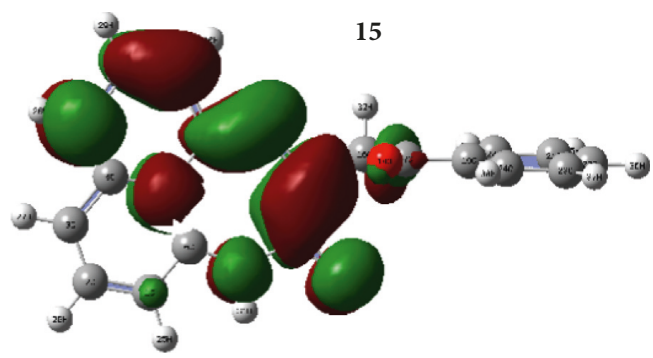

(d)

Figure 3: Continued. 


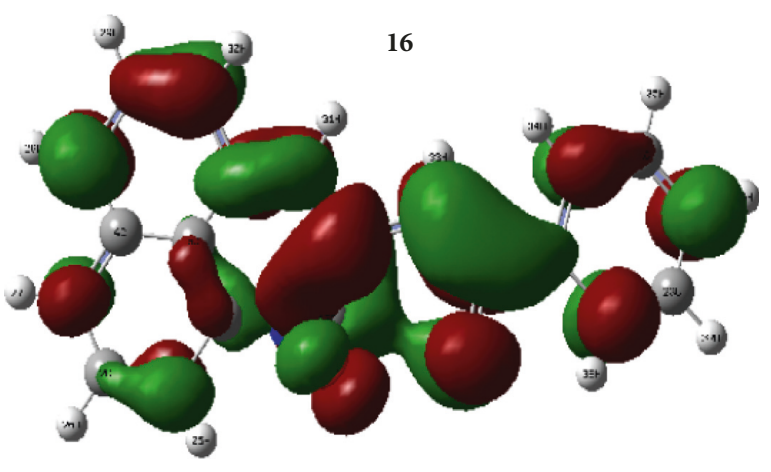

(e)

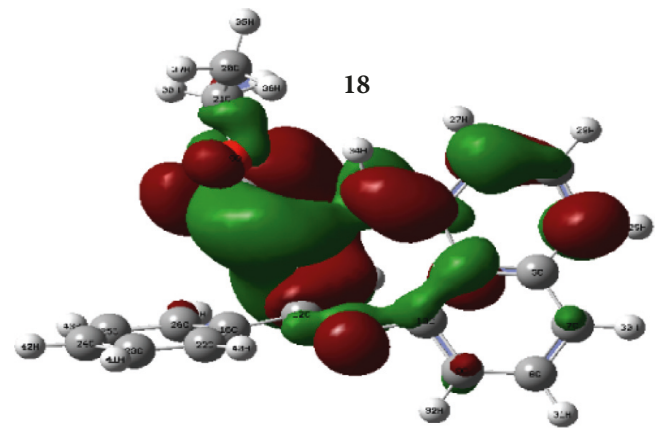

(g)

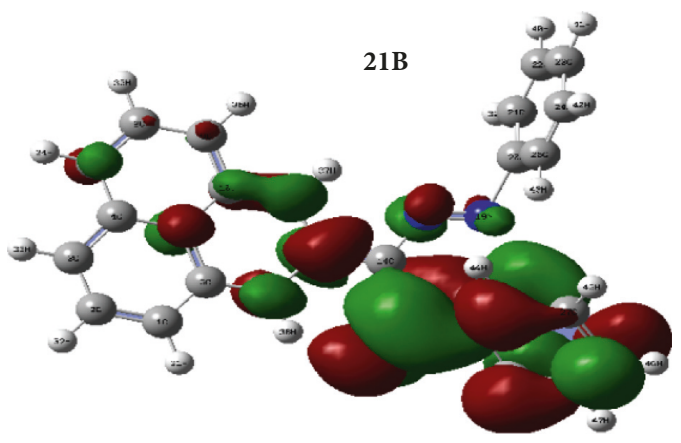

(i)

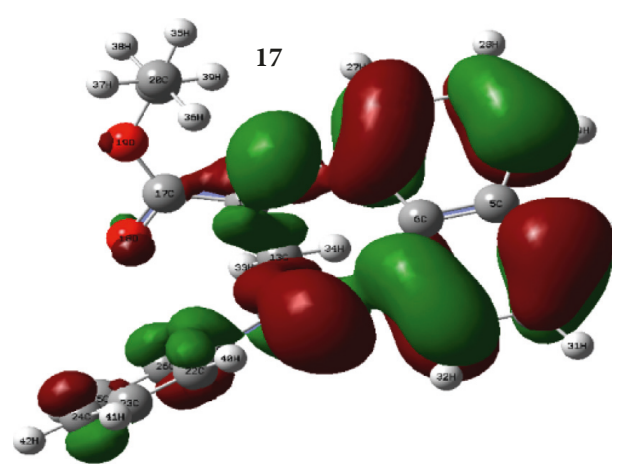

(f)

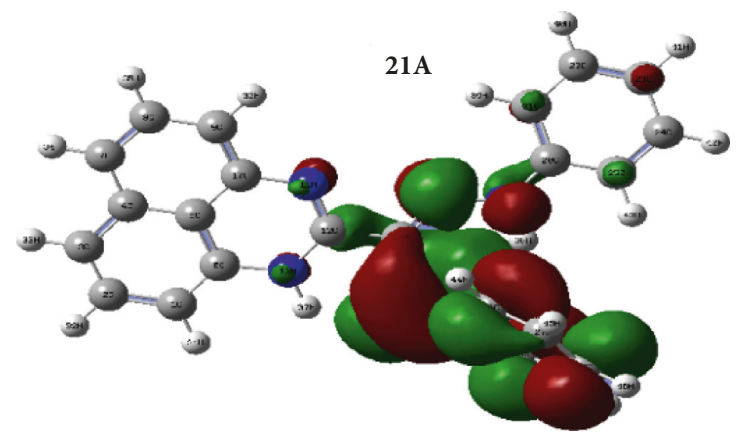

(h)

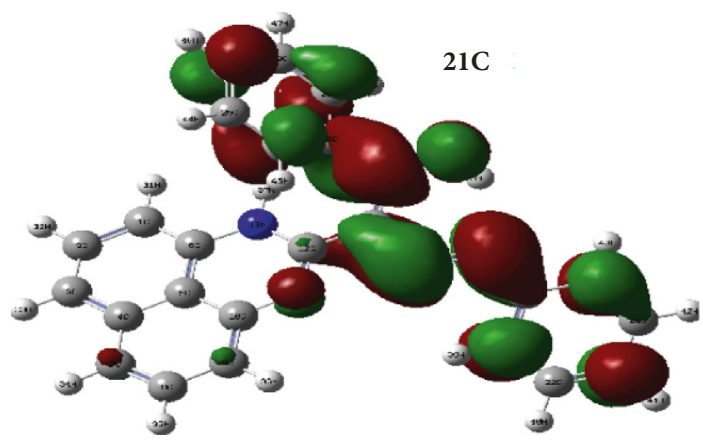

(j)

FIgURE 3: $(a-j)$ Frontier orbitals regarding the LUMO level for optimized structures.

TABLE 3: The activity of the tested compounds $12 a-e$ and $21 a-e$ against two fungi species.

\begin{tabular}{lccccc}
\hline Compound number & Aspergillus niger & Geotrichum candidum & Compound number & Aspergillus niger & Geotrichum candidum \\
\hline 12a & $19.4 \pm 0.63(83.3 \%)$ & $18.1 \pm 0.58(71.8 \%)$ & 21a & $17.3 \pm 1.2(74.2 \%)$ & $19.3 \pm 1.2(76.6 \%)$ \\
12b & $23.7 \pm 0.72(101.7 \%)$ & $24.4 \pm 1.2(96.8 \%)$ & 21b & $15.5 \pm 2.1(66.5 \%)$ & $14.2 \pm 2.1(56.3 \%)$ \\
12c & $19.6 \pm 0.63(84.4 \%)$ & $21.6 \pm 0.63(85.71 \%)$ & 21c & $24.1 \pm 1.2(103.4 \%)$ & $23.6 \pm 1.2(93.7 \%)$ \\
12d & $22.8 \pm 1.2(97.9 \%)$ & $20.7 \pm 0.72(82.1 \%)$ & $\mathbf{2 1 d}$ & $19.2 \pm 0.72(82.4 \%)$ & $17.3 \pm 0.72(68.7 \%)$ \\
12e & $19.4 \pm 0.63(83.3 \%)$ & $25.6 \pm 0.63(101.6 \%)$ & 21e & $12.9 \pm 0.72(55.4 \%)$ & $18.5 \pm 0.72(73.4 \%)$ \\
Amphotericin B & $23.3 \pm 0.58$ & $25.2 \pm 0.72$ & Amphotericin B & $23.3 \pm 0.58$ & $25.2 \pm 0.72$ \\
\hline
\end{tabular}

Data are expressed in the form of mean \pm SD.

The plates were then incubated at $37^{\circ} \mathrm{C}$ for $24 \mathrm{~h}$ and observed for antimicrobial activity. The diameters of the inhibition zone were measured and compared with the respective reference drug. The observed inhibition zones were measured in millimeter beyond well diameter. Each treatment was replicated three times, and the average value is recorded. Also, the percentage value of inhibition zones compared to reference drugs was recorded (Tables 3 and 4). 
TABLE 4: The activity of the tested compounds 12a-e and $21 \mathbf{a}-\mathbf{e}$ against four $\mathrm{G}^{+}$bacteria and four $\mathrm{G}^{-}$bacteria fungi species.

\begin{tabular}{|c|c|c|c|c|c|c|c|c|}
\hline \multirow{2}{*}{$\begin{array}{l}\text { Compound } \\
\text { number }\end{array}$} & \multicolumn{5}{|c|}{ Gram-positive bacteria } & \multicolumn{3}{|c|}{ Gram-negative bacteria } \\
\hline & $\begin{array}{c}\text { Staphylococcus } \\
\text { aureus }\end{array}$ & $\begin{array}{c}\text { Staphylococcus } \\
\text { epidermidis }\end{array}$ & $\begin{array}{l}\text { Bacillus } \\
\text { subtilis }\end{array}$ & $\begin{array}{c}\text { Streptococcus } \\
\text { pyogenes }\end{array}$ & $\begin{array}{c}\text { Pseudomonas } \\
\text { aeruginosa }\end{array}$ & $\begin{array}{c}\text { Escherichia } \\
\text { coli }\end{array}$ & $\begin{array}{c}\text { Klebsiella } \\
\text { pneumoniae }\end{array}$ & $\begin{array}{l}\text { Salmonella } \\
\text { typhimurium }\end{array}$ \\
\hline $12 \mathrm{a}$ & $\begin{array}{c}19.3 \pm 0.58 \\
(81.4 \%)\end{array}$ & $\begin{array}{c}17.4 \pm 0.58 \\
(77.7 \%)\end{array}$ & $\begin{array}{c}26.7 \pm 1.2 \\
(82.4 \%)\end{array}$ & NA & NA & $\begin{array}{c}24.3 \pm 0.63 \\
(95.7 \%)\end{array}$ & $\begin{array}{c}21.9 \pm 0.58 \\
(96.9 \%)\end{array}$ & $\begin{array}{c}20.4 \pm 0.72 \\
(87.6 \%)\end{array}$ \\
\hline $12 b$ & $\begin{array}{c}22.8 \pm 0.58 \\
(96.2 \%)\end{array}$ & $\begin{array}{c}21.6 \pm 0.72 \\
\quad(96.4)\end{array}$ & $\begin{array}{c}29.3 \pm 0.58 \\
(90.4 \%)\end{array}$ & NA & NA & $\begin{array}{c}24.2 \pm 0.72 \\
\quad(95.3 \%)\end{array}$ & $\begin{array}{c}20.3 \pm 0.63 \\
(89.8 \%)\end{array}$ & $\begin{array}{c}21.6 \pm 0.63 \\
(92.7 \%)\end{array}$ \\
\hline $12 \mathrm{c}$ & $\begin{array}{c}22.6 \pm 0.85 \\
(95.4 \%)\end{array}$ & $\begin{array}{c}19.6 \pm 1.2 \\
(87.5 \%)\end{array}$ & $\begin{array}{c}28.3 \pm 0.63 \\
\quad(87.3 \%)\end{array}$ & NA & NA & $\begin{array}{c}25.2 \pm 0.58 \\
(99.2 \%)\end{array}$ & $\begin{array}{c}18.6 \pm 1.2 \\
(82.3 \%)\end{array}$ & $\begin{array}{c}19.9 \pm 0.63 \\
(85.4 \%)\end{array}$ \\
\hline $12 d$ & $\begin{array}{c}21.2 \pm 0.63 \\
(89.5 \%)\end{array}$ & $\begin{array}{c}19.6 \pm 0.58 \\
(87.5 \%)\end{array}$ & $\begin{array}{c}27.3 \pm 0.53 \\
(84.3 \%)\end{array}$ & NA & NA & $\begin{array}{c}24.2 \pm 1.2 \\
(95.3 \%)\end{array}$ & $\begin{array}{c}22.1 \pm 0.44 \\
(97.8 \%)\end{array}$ & $\begin{array}{c}19.9 \pm 0.72 \\
(85.4 \%)\end{array}$ \\
\hline $12 \mathrm{e}$ & $\begin{array}{c}23.1 \pm 0.63 \\
(97.5 \%)\end{array}$ & $\begin{array}{c}22.7 \pm 0.72 \\
(101.3 \%)\end{array}$ & $\begin{array}{c}28.1 \pm 0.53 \\
(86.7 \%)\end{array}$ & NA & NA & $\begin{array}{c}18.5 \pm 1.2 \\
(72.8 \%)\end{array}$ & $\begin{array}{c}19.2 \pm 1.2 \\
(85.0 \%)\end{array}$ & $\begin{array}{l}20.4 \pm 0.58 \\
(87.6 \%)\end{array}$ \\
\hline $21 \mathrm{a}$ & $\begin{array}{c}16.7 \pm 0.63 \\
(70.5 \%)\end{array}$ & $\begin{array}{c}14.4 \pm 0.72 \\
(64.3 \%)\end{array}$ & $\begin{array}{c}19.2 \pm 0.63 \\
(59.3 \%)\end{array}$ & NA & NA & $\begin{array}{c}17.8 \pm 1.2 \\
(70.1 \%)\end{array}$ & $\begin{array}{c}17.3 \pm 1.2 \\
(76.5 \%)\end{array}$ & $\begin{array}{c}19.6 \pm 0.58 \\
(84.1 \%)\end{array}$ \\
\hline $21 b$ & $\begin{array}{c}15.2 \pm 1.2 \\
(64.1 \%)\end{array}$ & $\begin{array}{c}19.8 \pm 0.67 \\
(88.4 \%)\end{array}$ & $\begin{array}{c}24.3 \pm 0.58 \\
(75.0 \%)\end{array}$ & NA & NA & $\begin{array}{c}17.9 \pm 0.58 \\
(70.5 \%)\end{array}$ & $\begin{array}{c}13.3 \pm 0.58 \\
(58.8 \%)\end{array}$ & $\begin{array}{c}18.4 \pm 1.2 \\
(79.0 \%)\end{array}$ \\
\hline $21 \mathrm{c}$ & $\begin{array}{c}22.4 \pm 0.63 \\
(94.5 \%)\end{array}$ & $\begin{array}{c}20.9 \pm 0.72 \\
(93.3 \%)\end{array}$ & $\begin{array}{c}23.8 \pm 0.63 \\
(73.5 \%)\end{array}$ & NA & NA & $\begin{array}{c}24.3 \pm 1.2 \\
(95.7 \%)\end{array}$ & $\begin{array}{c}22.5 \pm 1.2 \\
(99.6 \%)\end{array}$ & $\begin{array}{c}26.3 \pm 0.58 \\
(112.9 \%)\end{array}$ \\
\hline 21d & $\begin{array}{c}13.5 \pm 1.2 \\
(57.0 \%)\end{array}$ & $\begin{array}{c}15.3 \pm 0.44 \\
(68.3 \%)\end{array}$ & $\begin{array}{l}18.2 \pm 0.58 \\
(56.2 \%)\end{array}$ & NA & NA & $\begin{array}{c}19.3 \pm 0.63 \\
(76.0 \%)\end{array}$ & $\begin{array}{c}16.3 \pm 0.63 \\
(72.1 \%)\end{array}$ & $\begin{array}{c}19.3 \pm 0.58 \\
(82.8)\end{array}$ \\
\hline $21 \mathrm{e}$ & $\begin{array}{c}15.3 \pm 0.43 \\
(64.6 \%)\end{array}$ & $\begin{array}{c}18.6 \pm 0.58 \\
(83.0 \%)\end{array}$ & $\begin{array}{c}22.4 \pm 0.53 \\
(69.1 \%)\end{array}$ & NA & NA & $\begin{array}{c}16.4 \pm 0.53 \\
(64.6 \%)\end{array}$ & $\begin{array}{c}20.4 \pm 0.53 \\
(90.3 \%)\end{array}$ & $\begin{array}{c}18.7 \pm 0.63 \\
(80.3 \%)\end{array}$ \\
\hline Ampicillin & $23.7 \pm 0.63$ & $22.4 \pm 1.2$ & $32.4 \pm 0.72$ & $24.5 \pm 0.63$ & - & - & - & - \\
\hline Gentamicin & - & - & - & - & $22.3 \pm 0.58$ & $25.4 \pm 1.2$ & $22.6 \pm 0.63$ & $23.3 \pm 0.58$ \\
\hline
\end{tabular}

NA: no activity; data are expressed in the form of mean \pm SD.

TABle 5: Docking energy values $(\mathrm{k} \mathrm{cal} / \mathrm{mol})$ for two best tautomers complexed with variable protein receptors.

\begin{tabular}{|c|c|c|c|c|c|c|c|c|c|}
\hline Ligands & $\mathrm{pK}_{1}-\mathrm{pK}_{2}$ & Receptor & $\begin{array}{l}\text { Estimated } \\
\text { free energy of } \\
\text { binding }\end{array}$ & $\begin{array}{c}\text { Estimated } \\
\text { inhibition } \\
\text { constant }\left(\mathrm{K}_{\mathrm{i}}\right) \\
(\mu \mathrm{M})\end{array}$ & $\begin{array}{c}\text { vdW + bond } \\
+ \text { desolve } \\
\text { energy }\end{array}$ & $\begin{array}{c}\text { Electrostatic } \\
\text { energy }\end{array}$ & $\begin{array}{c}\text { Total } \\
\text { intercooled } \\
\text { energy }\end{array}$ & Frequency & $\begin{array}{l}\text { Interaction } \\
\text { surface }\end{array}$ \\
\hline \multirow{11}{*}{$\begin{array}{l}\text { Compound } \\
12 a\end{array}$} & \multirow{14}{*}{$10.33-0.97$} & $1 \mathrm{ukc}$ & -6.55 & 15.80 & -6.22 & -0.07 & -6.29 & $20 \%$ & 585.749 \\
\hline & & 1 ydo & -5.81 & 55.13 & -5.52 & +0.01 & -5.50 & $10 \%$ & 569.54 \\
\hline & & 5022 & -4.67 & 375.04 & -4.54 & -0.17 & -4.71 & $10 \%$ & 487.392 \\
\hline & & 1thg & -4.72 & 346.39 & -4.15 & -0.09 & -4.24 & $40 \%$ & 473.189 \\
\hline & & $3 \mathrm{gdz}$ & -5.35 & 119.29 & -5.07 & -0.15 & -5.22 & $10 \%$ & 581.063 \\
\hline & & $2 w 7 q$ & -7.92 & 1.56 & -7.58 & -0.03 & -7.61 & $30 \%$ & 723.71 \\
\hline & & laf7 & -6.89 & 8.84 & -7.97 & -0.26 & -8.24 & $30 \%$ & 796.368 \\
\hline & & $1 \mathrm{bqb}$ & -5.06 & 196.91 & -5.72 & +0.08 & -5.64 & $50 \%$ & 681.073 \\
\hline & & $3 \mathrm{kp} 3$ & -5.32 & 126.03 & -5.25 & +0.10 & -5.15 & $30 \%$ & 585.688 \\
\hline & & 2esr & -6.76 & 11.05 & -6.71 & -0.05 & -6.76 & $40 \%$ & 585.867 \\
\hline & & $1 \mathrm{ukc}$ & -4.70 & 359.18 & -6.01 & -0.07 & -6.08 & $10 \%$ & 639.464 \\
\hline \multirow{3}{*}{$\begin{array}{l}\text { Compound } \\
\text { 21a }\end{array}$} & & 1ydo & -5.54 & 87.07 & -6.65 & -0.14 & -6.79 & $20 \%$ & 558.58 \\
\hline & & 5022 & -4.41 & 585.48 & -5.73 & -0.03 & -5.76 & $10 \%$ & 520.673 \\
\hline & & 1thg & -4.73 & 342.60 & -6.00 & -0.04 & -6.04 & $20 \%$ & 542.067 \\
\hline
\end{tabular}

The $\%$ activity $=\frac{\text { Mean zone of inhibition by test compound }(\mathrm{mm})}{\text { Mean zone of inhibition by standard }(\mathrm{mm})} \times 100$.

The obtained results of antifungal activity reflected variable activities of the tested compounds. Among the tested perimidine derivatives $\mathbf{1 2 b}$ and $\mathbf{2 1 c}$ was the most potent derivatives against Aspergillus niger with inhibition zones exceed the Amphotericin B $(101.7 \%$ and $103.4 \%$, respectively). In addition, compound $12 \mathrm{e}$ showed activity with $101.6 \%$ inhibition percent in comparison with the reference standard used (Table 3). The other derivatives revealed the activity ranging from excellent to good.

Investigating the Gram-positive bacterial activity results in Table 4, a highly potent activity was recorded for compounds $12 \mathbf{e}, \mathbf{1 2 b}$, and $21 \mathbf{c}$ against $S$. epidermidis with 


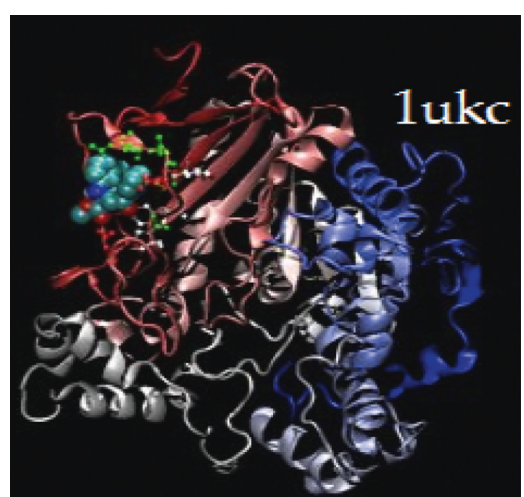

(a)

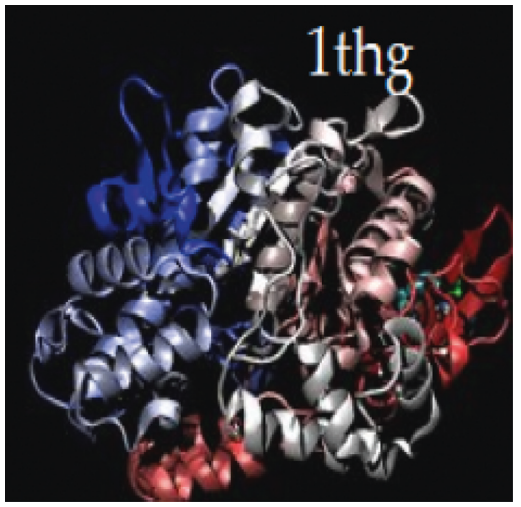

(d)

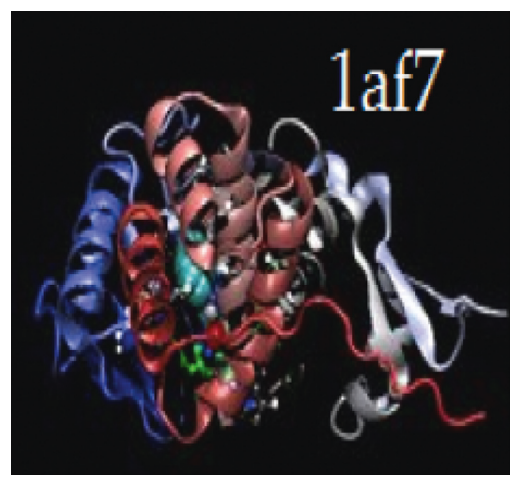

(g)

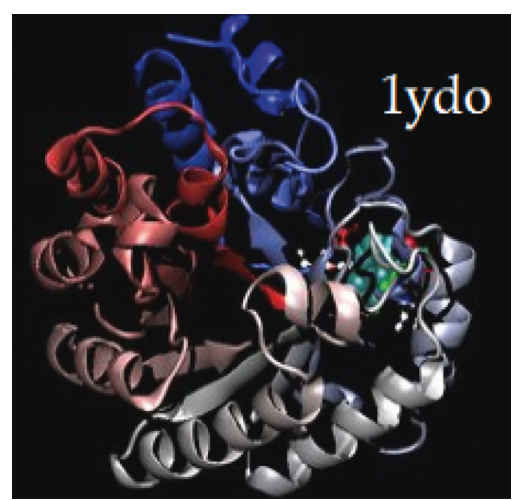

(b)

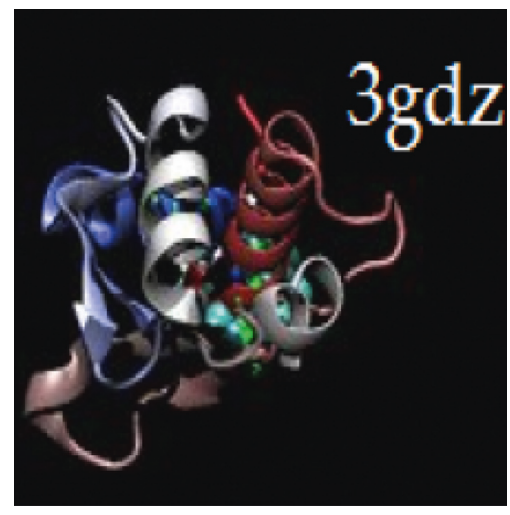

(e)

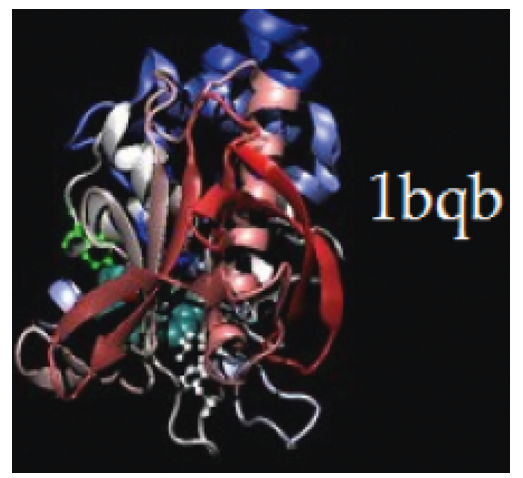

(h)

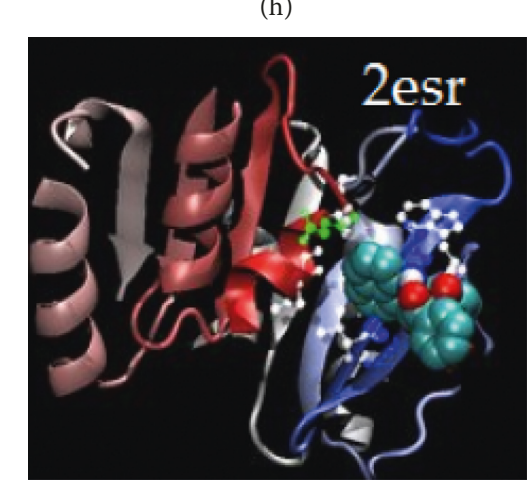

(j)

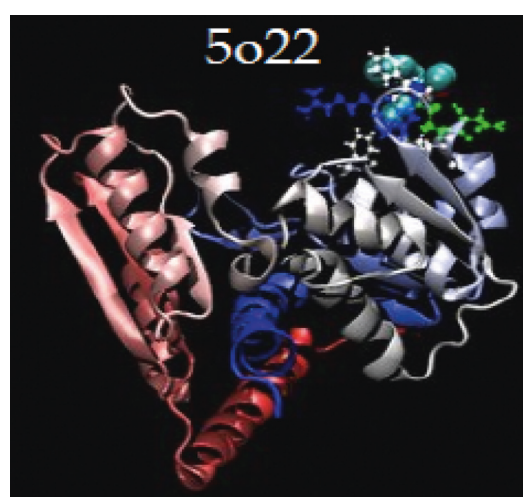

(c)

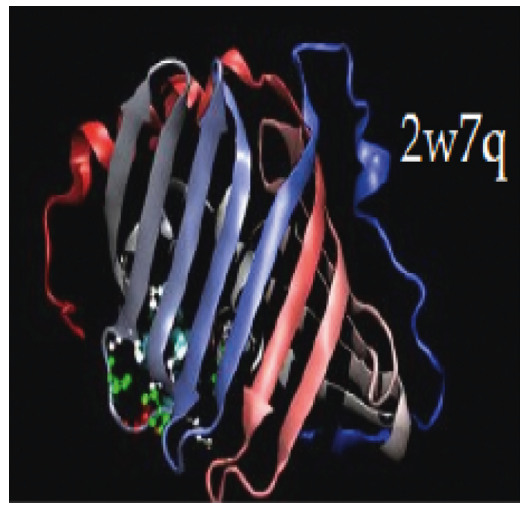

(f)

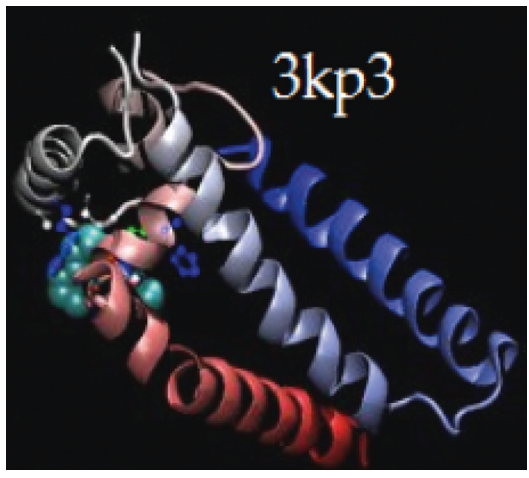

(i) 


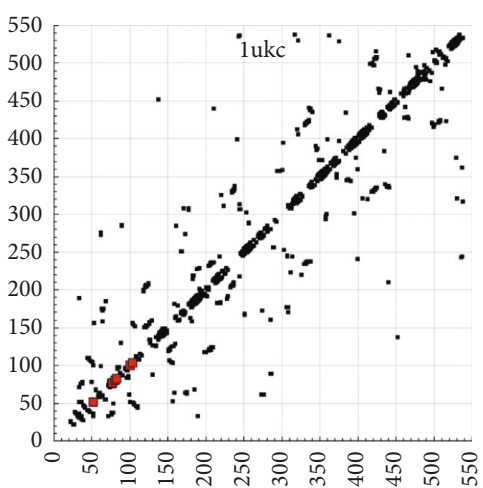

(a)

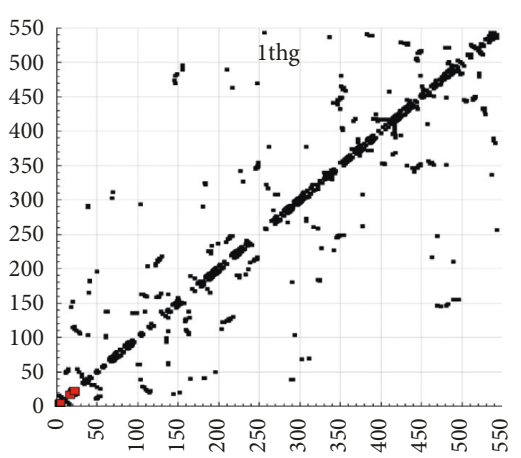

(d)

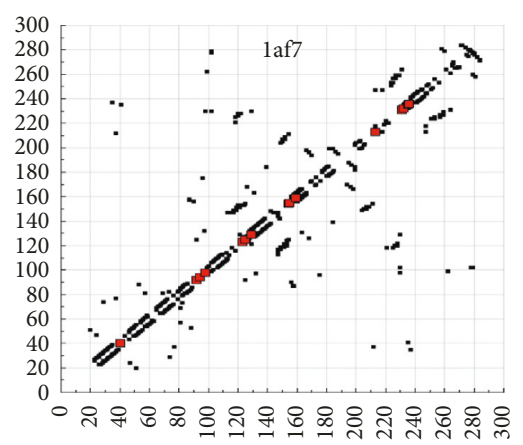

(g)

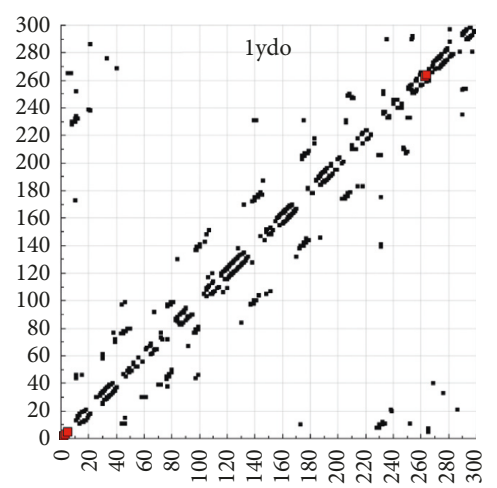

(b)

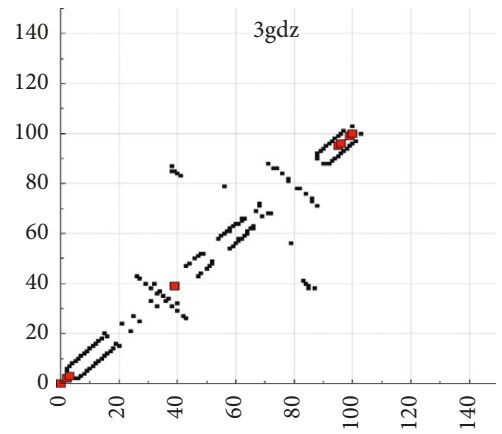

(e)

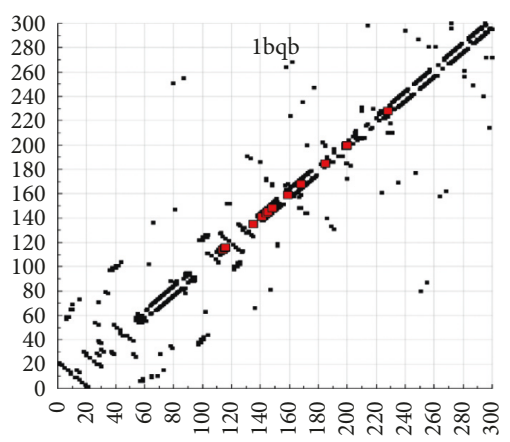

(h)

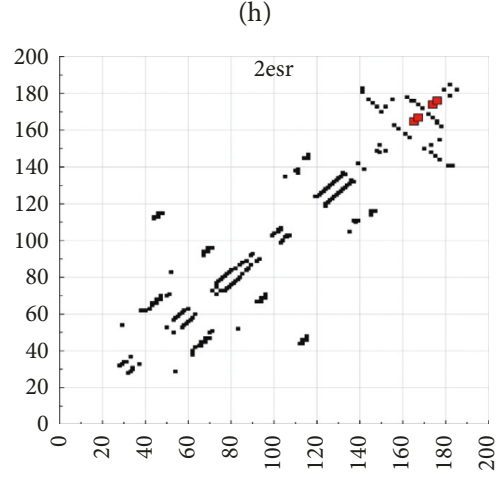

(j)

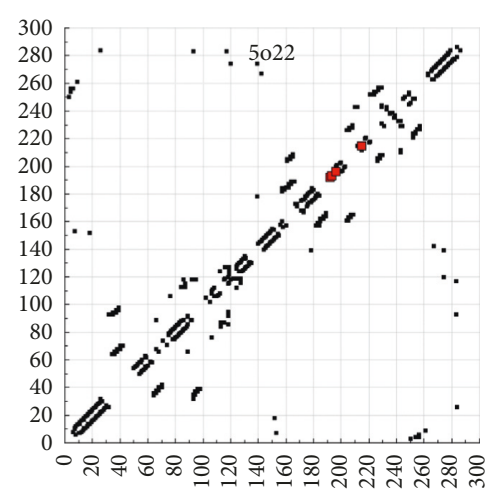

(c)

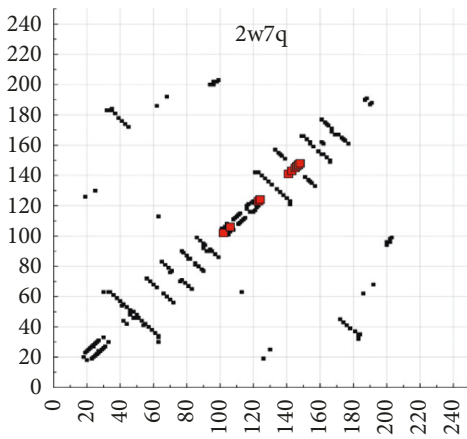

(f)

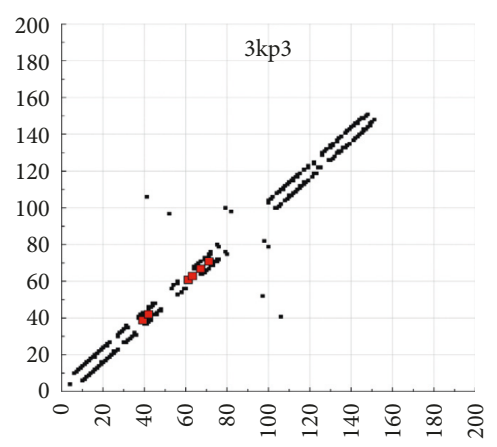

(i)

(b) 1ydo; (c) 5o22; (d) 1thg; (e) 3gdz; (f) 2w7q; (g) 1af7; (h) 1bqb; Figure 5: Hb plots
(i) $3 \mathrm{kp} 3$; (j) 2 esr.

inhibition percentages $101.3 \%, 96.4 \%$, and $93.3 \%$, respectively. The same derivatives in addition to $12 \mathrm{c}$ showed excellent activity when compared with ampicillin (the inhibition percentages ranging from 97.5 to $94.5 \%$ ).
Focusing on Gram-negative bacteria, all tested perimidine derivatives have no activity against $P$. aeruginosa, and in contrast, compound $21 \mathrm{c}$ is more reactive than gentamicin aganist $S$. typhimurium with inhibition percentage 
$112.9 \%$. The same derivative $21 \mathrm{c}$ also has activity similar to gentamicin against the Gram-negative bacteria Klebsiella pneumonia and Escherichia coli as shown in Table 4. In addition, perimidine derivatives $\mathbf{1 2 a}-\mathbf{d}$ and $2 \mathbf{e}$ was equipotent to gentamicin against some species (Table 4).

3.3. Molecular Docking Study. In the recent few decades, advanced development happened in the drug designing industry. Among this study was the computational method used to predicate the inhibition feature of the proposed drug against causative organism proteins. This study was achieved using AutoDock 4.2 tools to establish a comparative insight on the degree of inhibition toward pathogens. The receptors had chosen attributing to the tested bacteria and fungi in the experimental work. $1 \mathrm{ukc}$ and 1 thg were the protein receptors used which attribute to Aspergillus niger and Geotrichum candidum fungi. Whenever, $1 y d o, 5022,3 \mathrm{gdz}, 2 \mathrm{w} 7 \mathrm{q}, 1 \mathrm{af}$, $1 \mathrm{bqb}, 3 \mathrm{kp} 3$, and 2 esr were the protein receptors used, they attribute to Bacillis subtilis, Escherichia coli, Klebsiella pneumoniae, Pseudomonas aeruginosa, Salmonella typhimurium, Staphylococcus aureus, Staphylococcus epidermidis, and Streptococcus pyogenes bacteria. The data extracted upon docking complexes with proven compounds (12 and 21A) were displayed in Table 5. The values of free energy of binding and the inhibition constant display a moderate interaction between the two compounds and 1ukc and 1thg receptors. The values of total intercooled energy reflect the stability of docking complexes for such broad interaction surface. The docking complexes (Figure 4; Supplementary Figure 1S) display $\mathrm{H}$-bonding in the corner only with protein helix [28]. This conclusion coincided with a little extent of $\mathrm{H}$-bonding that appeared in the $\mathrm{Hb}$ plots (Figure 5; Supplementary Figure 2S) which exhibit interaction over the siding part in broad helix. However, variable features appeared against bacterial pathogen proteins. The best interaction was displayed with 1 af7 and 1 bqb receptors attributing to Salmonella typhimurium and Staphylococcus aureus organisms. This is concluded from the reduced energies (Table 5) over broad interacting surfaces. However, moderate inhibition was expected with the two tested compounds (12 and 21A) versus rest proteins. The docking complexes (Figure 4; Supplementary Figure 1S) display high occlusion for the two compounds with 1af7 or $1 \mathrm{bqb}$ protein helix. This was confirmed upon the $\mathrm{Hb}$ plots (Figure 5; Supplementary Figure 2S) which display the best distribution of intra-H-bonding with two reported receptors. But, on the other side, a little extent for $\mathrm{H}$-bonding was recorded upon rest protein helix though broad interaction surfaces. Finally, this simulation process coincided by an excellent way with the experimental screening work which displays a moderate inhibition against most organisms considered.

\section{Conclusion}

The mechanism of the reaction of 1,8-diaminonaphthalene with ethyl aroylpyrovate was discussed using all possible spectroscopic tools as well as the computational study by applying Guassian09 software. In addition, the antimicrobial activity of all products was screened. The results of such study indicated that three derivatives $12 \mathrm{~b}, 12 \mathrm{e}$, and $21 \mathrm{c}$ have impacts on the fungi and bacteria more than the reference drugs used. However, the theoretical study of the antimicrobial activity of two derivatives 12a and 21a as examples of the synthesized series using AutoDock 4.2 tools indicated that such derivatives have moderate activity for all fungi and bacteria species.

\section{Data Availability}

The data used to support the findings of this study are available from the corresponding author upon request.

\section{Conflicts of Interest}

The author declares that there are no conflicts of interest.

\section{Supplementary Materials}

Figures are given for docking complexes for compound $\mathbf{2 1 A}$ with variable protein receptors (Figure 1S), Hb plots for the compound 21A-protein complexes (Figure 2S), and spectral data for all compounds such as FTIR spectra (Figures S3S9), mass spectra (Figures 10S-19S), and NMR spectra (Figures S20-S28) are available on the journal's website. (Supplementary Materials)

\section{References}

[1] H. Kabiri-fard, S. Balalaie, S. Abbasian, and A. Panjalizadeh, "Reactions of 3-arylhydrazono-2,4-dioxo-4-phenylbutanoates with dinucleophiles," Journal of Applied Chemistry Research, vol. 4, no. 14, pp. 33-37, 2010.

[2] C. M. Atkinson, C. W. Brown, and J. C. E. Simpson, "6. Cinnolines and other heterocyclic types in relation to the chemotherapy of trypanosomiasis. Part XI. Some reactions of simple quinoxaline derivatives," Journal of the Chemical Society (Resumed), pp. 26-30, 1956.

[3] B. Kołodziej, M. Morawiak, B. Kamie_nski, and W. Schilf, "The structure investigations of dehydroacetic acid and 1,8diaminonaphthalene condensation product by NMR, MS, and X-ray measurements," Journal of Molecular Stracture, vol. 1112, pp. 81-86, 2016.

[4] W.-Z. Chen, H.-Y. Wie, and D.-Y. Yang, "Visible lightsensitive properties of 1,2-dimethyl-2-(2-nitrophenyl)-2,3dihydro-1H-perimidine," Tetrahedron, vol. 69, no. 13, pp. 2775-2781, 2013.

[5] I. Koca, E. H. Ngren, B. E. Kbrz, and F. Ylmaz, "The synthesis of new pyrrolo[1,2-a]perimidin-10-one dyes via two convenient routes and its characterizations," Dyes and Pigments, vol. 95, no. 2, pp. 421-426, 2012.

[6] S. Anga, S. Biswas, R. K. Kottalanka, B. S. Mallik, and T. K. Panda, "Structural and mechanistic insights of substituted perimidine-experimental and computational studies," Canadian Chemical Transactions, vol. 2, no. 1, pp. 72-82, 2014.

[7] G. Varsha, V. Arun, P. P. Robinson et al., "Two new fluorescent heterocyclic perimidines: first syntheses, crystal structure, and spectral characterization," Tetrahedron Letters, vol. 51, no. 16, pp. 2174-2177, 2010. 
[8] C.-K. Wu, T.-J. Liou, P.-S. Tsai, and D.-Y. Yang, "Visible light photoredox catalysis: aerobic oxidation of perimidines to perimidinones," Tetrahedron, vol. 70, no. 44, pp. 8219-8225, 2014.

[9] I. A. S. Smellie, A. Fromm, and R. M. Paton, "A new route to 2-substituted perimidines based on nitrile oxide chemistry," Tetrahedron Letters, vol. 50, no. 28, pp. 4104-4106, 2009.

[10] A. F. Pozharskii and V. V. Dalnikovskaya, "Perimidines," Russian Chemical Reviews, vol. 50, no. 9, pp. 816-835, 1981.

[11] J. M. Herbert, P. D. Woodgate, and W. A. Denny, "Potential antitumor agents 53. Synthesis, DNA binding properties, and biological activity of perimidines designed as minimal DNAintercalating agents," Journal of Medicinal Chemistry, vol. 30, no. 11, pp. 2081-2086, 1987.

[12] X. Bu, L. W. Deady, G. J. Finlay, B. C. Baguley, and W. A. Denny, "Synthesis and cytotoxic activity of 7-Oxo-7Hdibenz[f,ij] isoquinoline and 7-Oxo-7H-benzo[e]perimidine derivatives," Journal of Medicinal Chemistry, vol. 44, no. 12, pp. 2004-2014, 2001.

[13] V. V. Patil and G. S. Shankarling, "A metal free, eco-friendly protocol for the synthesis of 2,3-dihydro-1H-perimidines using commercially available Amberlyst 15 as a catalys," Catalysis Communication, vol. 57, pp. 138-142, 2014.

[14] W. Bauer and M. Akram, "Hair coloring compositions which contain developers and perimidine couplers," vol. 25, U S Patent 5,613,985, 1997.

[15] S. Goswami, D. Sen, and N. K. Das, "A new highly selective, ratiometric and colorimetric fluorescence sensor for $\mathrm{Cu} 2+$ with a remarkable red shift in absorption and emission spectra based on internal charge transfer," Organic Letters, vol. 12, pp. 856-859, 2010.

[16] P. Herold, A. F. Indolese, M. Studer, H. P. Jalett, U. Siegrist, and H. U. Blaser, "New technical synthesis of ethyl $(R)-2-$ Hydroxy-4-phenylbutyrate of high enantiomeric purity," Tetrahedron, vol. 56, no. 35, pp. 6497-6499, 2000.

[17] A. Schmidt, T. Habeck, M. K. Kindermann, and M. Nieger, "New pyrazolium-carboxylates as structural analogues of the pseudo-cross-conjugated betainic alkaloid nigellicine," Journal of Organic Chemistry, vol. 68, no. 15, pp. 5977-5982, 2003.

[18] S. V. Ryabukhin, A. S. Plaskon, S. S. Bondarenko et al., "Acyl pyruvates as synthons in the Biginelli reaction," Tetrahedron Letters, vol. 51, no. 32, pp. 4229-4232, 2010.

[19] M. J. Frisch, Gaussian 09, Revision D, Gaussian, Inc., Wallingford, CT, USA, February 2010.

[20] I. Althagafi, M. G. Elghalban, F. Saad et al., "Spectral characterization, CT-DNA binding, DFT/B3LYP, molecular docking and antitumor studies for new nano-sized VO(II)hydrazonoyl complexes," Journal of Molecular Liquids, vol. 242, pp. 662-677, 2017.

[21] J. J. P Stewart, "Optimization of parameters for semiempirical methods V: modification of NDDO approximations and application to 70 elements," Journal of Molecular Modeling, vol. 13, no. 12, pp. 1173-1213, 2007.

[22] T. A. Farghaly and H. K. Mahmoud, "Synthesis, tautomeric structures and antitumor activity of new perimidines," Archive of pharmacy, vol. 346, no. 5, pp. 392-402, 2013.

[23] T. A. Halgren, "Merck molecular force field. I. Basis, form, scope, parameterization, and performance of MMFF94," Journal of Computational Chemistry, vol. 17, no. 5-6, pp. 490-519, 1996.

[24] G. M. Morris, D. S. Goodsell, R. S. Halliday et al., "Automated docking using a lamarckian genetic algorithm and and empirical binding free energy function," Journal of Computational Chemistry, vol. 19, no. 14, pp. 1639-1662, 1998.

[25] F. J. Solis and R. J. B. Wets, "Minimization by random search techniques," Mathematics of Operations Research, vol. 6, no. 1, pp. 19-30, 1981.

[26] R. R. Phillips, “The Japp-Klingemann reaction," in Organic Reactions, pp. 143-178, Wiley, Hoboken, NJ, USA, 2011.

[27] M. Balouiri, M. Sadiki, and S. K. Ibnsouda, "Methods for in vitro evaluating antimicrobial activity: a review," Journal Pharmaceutical Analysis, vol. 6, no. 2, pp. 71-79, 2016.

[28] K. Tripathi, R. Muttineni, and S. K. Singh, "Extra precision docking, free energy calculation and molecular dynamics simulation studies of CDK2 inhibitors," Journal of Theoretical Biology, vol. 334, pp. 87-100, 2013. 

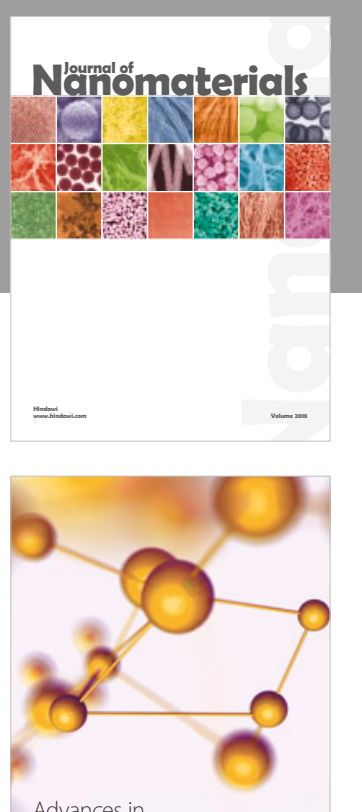

Physical Chemistry
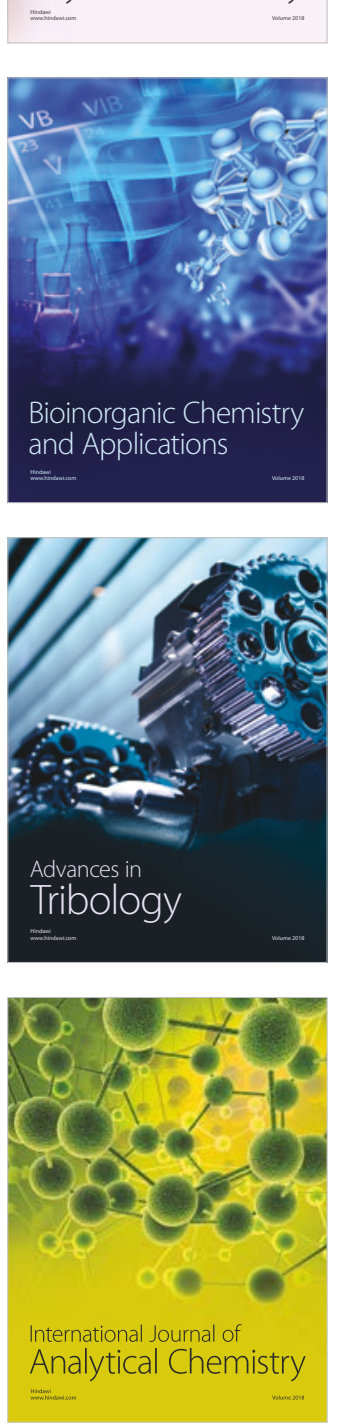

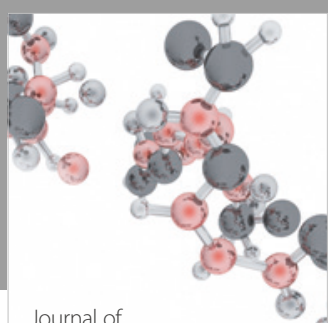

Analytical Methods

in Chemistry

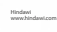

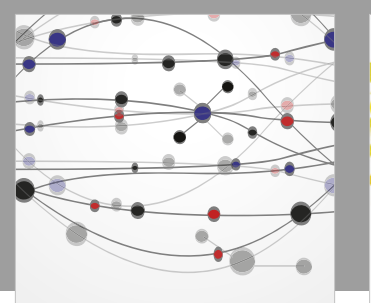

The Scientific World Journal

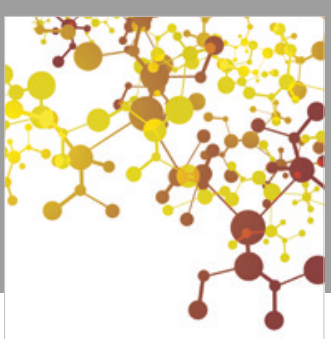

Journal of

Applied Chemistry
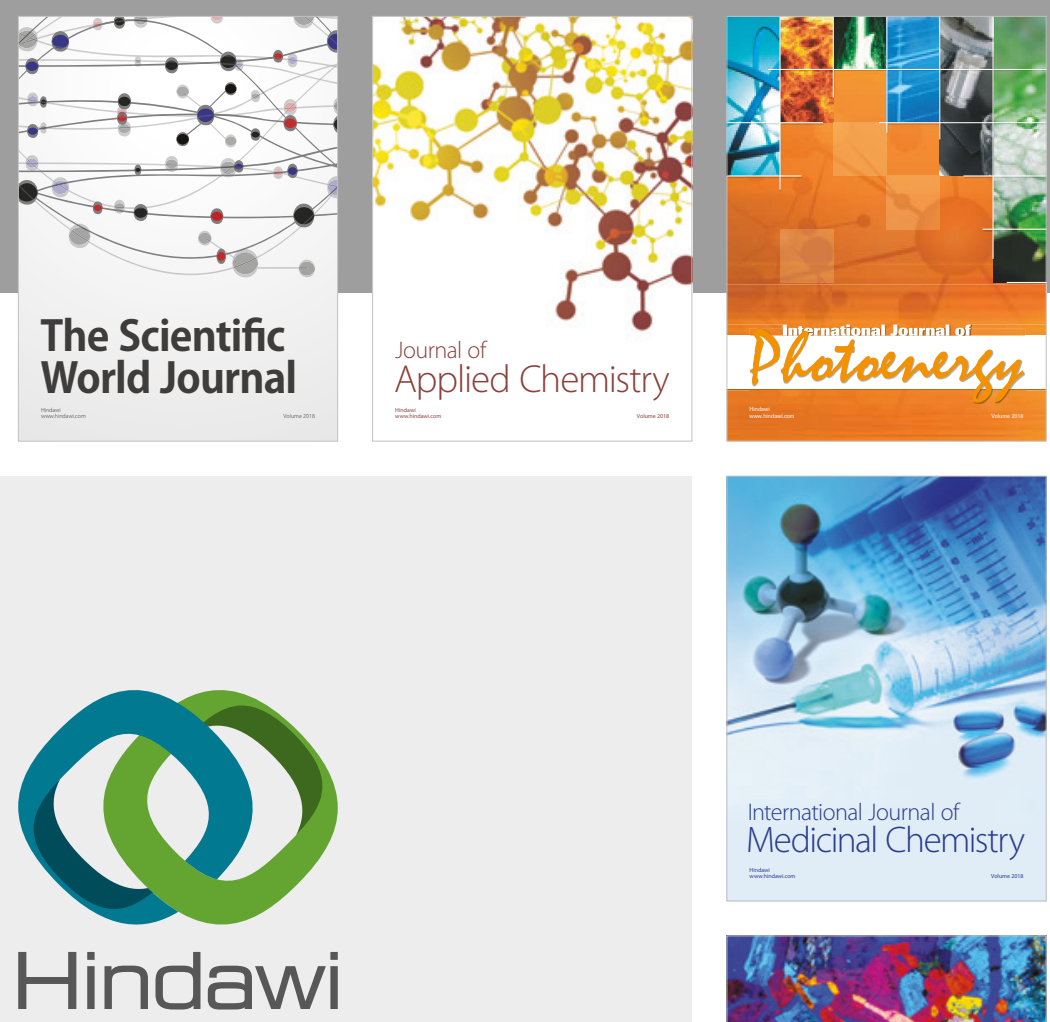

Submit your manuscripts at

www.hindawi.com
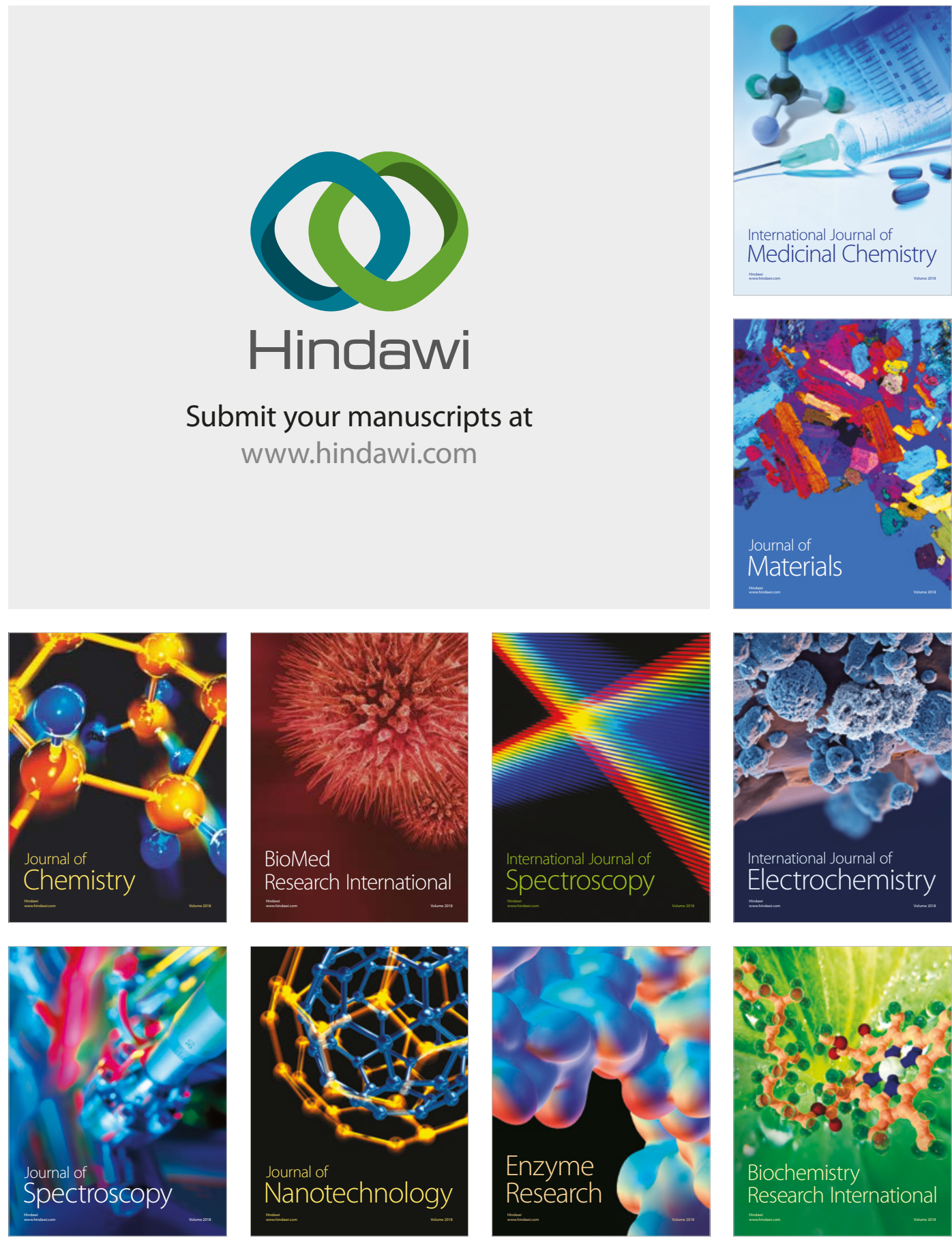
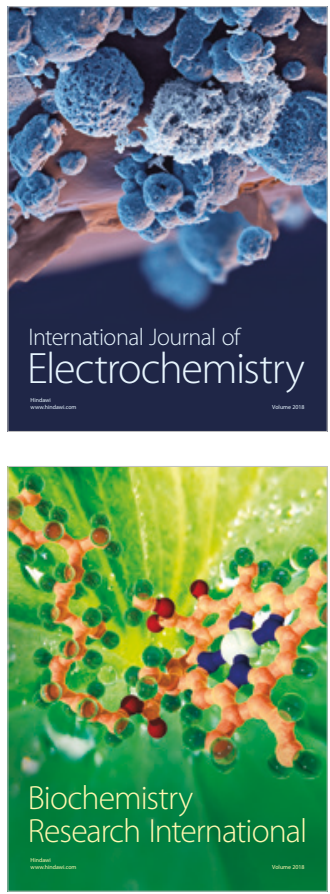